\title{
Preparation of
}

CoFe204@Carboxymethylcellulose/HZSM-5 as a Novel Nano Magnetic Adsorbent for Metronidazole Removal: Isotherm, Kinetic and Thermodynamic

\section{Study}

\section{Alireza Nasiri}

Kerman University of Medical Sciences

Mohammad Reza Heidari

Bam University of Medical Sciences

Neda Javid

Kerman University of Medical Sciences

Ghazal Yazdanpanah ( $\nabla$ ghazal.yazdanpanad@gmail.com )

Kerman University of Medical Sciences https://orcid.org/0000-0003-1427-3336

\section{Research Article}

Keywords: Metronidazole, Carboxymethylcellulose, Adsorption

Posted Date: July 12th, 2021

DOl: https://doi.org/10.21203/rs.3.rs-689828/v1

License: (c) (i) This work is licensed under a Creative Commons Attribution 4.0 International License.

Read Full License 


\title{
Preparation of $\mathrm{CoFe}_{2} \mathrm{O}_{4} @$ Carboxymethylcellulose/HZSM-5 as a Novel Nano magnetic Adsorbent for Metronidazole Removal: Isotherm, Kinetic and Thermodynamic Study
}

\author{
Alireza Nasiri ${ }^{1}$, Mohammad Reza Heidari ${ }^{2}$, Neda Javid ${ }^{3}$, Ghazal Yazdanpanah ${ }^{1 *}$ \\ ${ }^{1}$ Environmental Health Engineering Research Center, Kerman University of Medical Sciences, \\ Kerman, Iran \\ ${ }^{2}$ Environmental Health Engineering, Department of Environmental Health, School of Public Health, \\ Bam University of Medical Sciences, Bam, Iran \\ ${ }^{3}$ Department of Environmental Health, Zarand School of Nursing, Kerman University of Medical \\ Sciences, Kerman, Iran \\ *Corresponding author: Ghazal Yazdanpanah, Environmental Health Engineering Research Center, \\ Department of Environmental Health, Kerman University of Medical Sciences, Kerman, Iran; Fax: \\ +983432268056; E-mail: ghazal.yazdanpanad@gmail.com, g.yazdanpanah@kmu.ac.ir
}

\begin{abstract}
In this research $\mathrm{CoFe}_{2} \mathrm{O}_{4} @ \mathrm{CMC} / \mathrm{HZSM}-5$ synthesized in the presence of Carboxymethylcellulose as a biopolymer in the green conditions as a new nanomagnetic adsorbent for metronidazole removal from aqueous media. Physical and chemical structure of adsorbent was investigated by FTIR, FESEM, EDS, Mapping, TEM, XRD, VSM, BET and TGA techniques. The results indicated that $94 \%$ of the metronidazole concentration removed by $\mathrm{CoFe}_{2} \mathrm{O}_{4} @ \mathrm{CMC} / \mathrm{HZSM}-5$ in the optimal conditions including $\mathrm{pH} 6$, temperature $20^{\circ} \mathrm{C}$, metronidazole concentration $50 \mathrm{mg} / \mathrm{L}$, contact time $60 \mathrm{~min}$ and adsorbent dose $2 \mathrm{~g} / \mathrm{L}$. The resulting data from adsorption experimental experiments had better correlated with the Freundlich isotherm and pseudo-second order kinetic. Also, the thermodynamic study demonstrated that the adsorption process was an endothermic process and had a physical mechanism. As well as, the achieved findings demonstrated that following six adsorption runs, the adsorbent chemical structure had no change and the nanomagnetic adsorbent efficiency in the removal process had a slight decrease. $\mathrm{CoFe}_{2} \mathrm{O}_{4} @ \mathrm{CMC} / \mathrm{HZSM}-5$ magnetic nanocomposite had effective adsorption capacity for metronidazole removal.
\end{abstract}

Keywords: Metronidazole, Carboxymethylcellulose, Adsorption 


\section{Introduction}

About $30-90 \%$ of antibiotics are not metabolized in the animal and human bodies. Eventually, they enter the environment through the urine and stool in the form of active compounds. The hospital wastewater is the main source of antibiotics in the environment [1,2]. Medications and antibiotics are the most important groups of emerging pollutants. These organic compounds enter the water sources in two ways. One of these pollution sources is the pharmaceutical industry wastewater and the other one is excretion of the medicines compounds metabolites due to their incomplete metabolism during treatment. Because of the ability of these compounds to alter ecosystems and reduce biodiversity, removal of these compounds from the aquatic environments is so important [3].

Metronidazole is one of the nitroimidazole antibiotics group which has antibacterial and antiinflammatory properties and it can be used to treat diseases that caused by anaerobic bacteria, protozoa, and bacteroides. Metronidazole is one of the most commonly used antibiotics in the world which is in the WHO's list of essential medicines. Metronidazole, like other antibacterial and antioxidant medicines which have nitroimidazole ring structure, is suspicious to causes carcinogenic and mutagenic [4]. By reason of the non-biodegradability, toxicity, mutagenic and carcinogenic potential of metronidazole, the wastewater containing this antibiotic causes harmful effects on the humans and ecological environment so, removal of metronidazole has environmental, technical and economic importance [5].

Removal of complex organic compounds such as antibiotics from water resources with conventional filtration methods due to their sustainability in the environment and nonbiodegradable structure is so difficult. Purification processes including ion exchange [6], membrane filtration [7], solvent extraction [8], electrochemical methods [9], chemical precipitation [10], biological methods [11], electrochemical oxidation [12], catalytic [13, 14] and fenton oxidation $[15,16]$ are used for water treatment.

The mentioned methods have some disadvantages. For example disadvantages of the membrane filtration process are the membrane blockage owing to the chemical sediment growth formation and the physicochemical properties changes of the membrane surface [17]. In the biological methods, during the treatment process, high concentrations antibiotics could make toxicity. The other problem is resistance of some antibiotics against biological treatment. In addition, the chemical methods because of sludge production and need to chemical materials are costly and not popular [18].

The adsorption process compared to the other mentioned methods has more high efficiency, simple design and operation, low cost and non-production of hazardous materials, which are basic features of the adsorption process. Therefore, many researchers focus on its use in the environmental pollutants removal [19].

Some of adsorbents such as activated carbon, ash, coal, metal oxides, agricultural wastes, kaolinite, bagasse, resins, and compost are used as adsorbents to removal of heavy metals and some organic compounds from the aquatic environments. But, some of these adsorbents show low adsorption efficiency since their low surface areas and adsorption capacities. Also, separate those from the environment by filtration and centrifugation methods is time-consuming. In 
most cases, the adsorbent passes through the filter and leads to the secondary pollution production in the environment [20-24].

To solve this problem, magnetic nanoadsorbents are used. One of the most widely used adsorbents is magnetic nanocomposites [25-27]. Magnetic nanocomposites due to their good magnetic property, high area surface and adsorption capacity have attracted the many researchers attention. In a lot of researches, nanocomposites which contain some of biopolymers such as cellulose, methylcellulose, carboxymethylcellulose, and chitosan in their structure, are used as bioadsorbents in water treatment processes [28, 29].

The mentioned polysaccharide compounds owing to cross-links and functional groups such as $\mathrm{OH}, \mathrm{NH}_{2}, \mathrm{COOH}, \mathrm{COONa}$ in their structure can be easily dissolved in water and cause electrostatic interaction between the adsorbent and the contaminant [30]. These polysaccharide derivatives have some advantages such as availability, biodegradability and non-toxicity. Therefore, they are widely used as adsorbents for the pollutants removal from aquatic environments [31]. Cellulose derivatives such as Methylcellulose (MC), hydroxypropyl methylcellulose (HPMC), ethylcellulose (EC) and carboxymethylcellulose (CMC) are used in the various nanocomposites preparation for water treatment process [32]. Using raw cellulose because of some disadvantages such as lower solubility, inability to reuse, poor interaction with pollutants and low surface area is limited. So, to solve this problem, the nanocomposites combined with ionic functionalization, ester, and the etheric cellulose derivatives are used which can produce advanced material based on the cellulose derivatives [33, 34]. Among these derivatives, $\mathrm{CMC}$ is a frequently used cellulose derivative and soluble in the water, which is used as an adsorbent in the water purification process. CMC as a biopolymer is sensitive to $\mathrm{pH}$ changes [35]. Use of these adsorbents could make some limitations such as filtration, dispersion, turbidity, secondary contamination and high cost of regeneration. Therefore, create conditions for optimal use of CMC and other nanoscale or powdered adsorbents could make magnetic property in them through compression with metal ferrite compounds [36]. Polysaccharide-based composites owing to their impressive properties such as high surface area, chemical stability and mechanical strength have attracted great attention to themselves [37].

To enhance properties of these composites including physiochemical and adsorption capability, some various materials such as montmorillonite [38], bentonite [39], alumina [40], kaolin [41], and zeolite [42] have been used in their preparation. HZSM-5 zeolite by reason of some properties like low priced, diversity of structural properties, good mechanical firmness, high surface area, and high adsorption valence towards cation species was utilized as a solo adsorbent or composite in the water pollutants removal [43]. In the field of pollutants removal from water and wastewater HZSM -5 zeolite composites are receiving increased attention. In previous research about pollutants removal from aqueous, various ferritic cellulose derivatives such as $\mathrm{ZnFe}_{2} \mathrm{O}_{4} @ \mathrm{CMC}, \mathrm{ZnFe}_{2} \mathrm{O}_{4} @ \mathrm{CMC}, \mathrm{CuFe}_{2} \mathrm{O}_{4} @ \mathrm{MC}$ and $\mathrm{CoFe}_{2} \mathrm{O}_{4} / \mathrm{AC} @$ chitosan due to the renewability, cellulose stable nature reasonable price, and availability have been prepared and applied as sorbents or photocatalysts [33, 34]. Also, several cellulosic adsorbents such as attapulgite/chitosan (ATP/CS) [44], chitosan-cellulose enwrapped magnetic carbon foam (CCMF), carboxylated cellulose/ $\mathrm{MnFe}_{2} \mathrm{O}_{4}$ aerogel [45], magnetic-PEI-cellulose [46], 
$\mathrm{Fe}_{3} \mathrm{O}_{4} @ \mathrm{SiO}_{2} @$ Cellulose [47], $\mathrm{Fe}_{3} \mathrm{O}_{4} @ \mathrm{CMC} @ \mathrm{PDA}$ [48][49], grafted magnetic cellulose with thiol/amine (GMC-N/S)[50], magnetic carboxylated cellulose nanocrystal composite (CCN$\mathrm{Fe}_{3} \mathrm{O}_{4}$ ) [51], Magnetic chitosan/cellulose [52], magnetic hydrogel beads (m-CS/PVA/CCNFs) [53], amino-functionalized magnetic cellulose composite [49], magnetic cellulose-chitosan hydrogels have been used for the pollutants removal from aqueous solutions [48].

In this research CMC that applied in the synthesis of the HZSM, played an essential role to improve the $\mathrm{CoFe}_{2} \mathrm{O}_{4} @ \mathrm{CMC} / \mathrm{HZSM}-5$ nanoadsorbent structural features. CMC in the $\mathrm{CoFe}_{2} \mathrm{O}_{4} @ \mathrm{CMC} / \mathrm{HZSM}-5$ composition caused increasing the adsorbent surface area. As well as, carboxyl and hydroxyl groups in CMC create the electrostatic attraction between metronidazole and $\mathrm{CoFe}_{2} \mathrm{O}_{4} @ \mathrm{CMC} / \mathrm{HZSM}-5$ composite surface. $\mathrm{CoFe}_{2} \mathrm{O}_{4} @ \mathrm{CMC} / \mathrm{HZSM}-5$ was prepared with highly efficient microwave-assisted co-precipitation method by iron and cobalt salts on CMC in the presence of HZSM-5 and was used in highly efficient adsorption of the metronidazole. $\mathrm{CoFe}_{2} \mathrm{O}_{4} @ \mathrm{CMC} / \mathrm{HZSM}-5$ that was used as a nanomagnetic adsorbent in the adsorption process to remove contaminants was easily separated from aqueous solutions as well as recycled and reused. According to the literature, the purpose of this investigation is preparation and characterization of $\mathrm{CoFe}_{2} \mathrm{O}_{4} @ \mathrm{CMC} / \mathrm{HZSM}-5$ as a new nanomagnetic adsorbent for metronidazole removal.

\section{Materials and Methods}

\subsection{Materials and equipment}

All the required materials for this study, including carboxymethylcellulose (CMC), iron chloride $\left(\mathrm{FeCl}_{3} \cdot 6 \mathrm{H}_{2} \mathrm{O}\right)$, cobalt chloride $\left(\mathrm{CoCl}_{2} \cdot 6 \mathrm{H}_{2} \mathrm{O}\right)$ and nitric acid $\left(\mathrm{HNO}_{3}\right)$, were purchased from Merck (Germany). All used solutions in the study were prepared from high purity deionized water (DW). The solutions $\mathrm{pH}$ were adjusted using chlorinated hydrochloric acid $(\mathrm{HCl})$ and 0.1 molar sodium hydroxide $(\mathrm{NaOH})$ and were measured by using $\mathrm{pH}$ meter (HACH-HQ-USA). In order to adsorbent magnetic separation from the solution, a cubic magnet with a magnetic intensity of 1.3 Tesla was used. The metronidazole was bought from DarouPakhsh Holding Company (Iran).

\subsection{Preparation of $\mathrm{CoFe}_{2} \mathrm{O}_{4} @ \mathrm{CMC} / \mathrm{HZSM}-5$}

The magnetic nanocomposite was prepared using iron chloride $\left(\mathrm{FeCl}_{3} \cdot 6 \mathrm{H}_{2} \mathrm{O}\right)$, cobalt chloride $\left(\mathrm{CoCl}_{2} .6 \mathrm{H}_{2} \mathrm{O}\right)$ salts, carboxymethylcellulose $(\mathrm{CMC})$ and $/ \mathrm{HZSM}-5$ zeolite. At first, salts of iron chloride $\mathrm{FeCl}_{3} \cdot 6 \mathrm{H}_{2} \mathrm{O}$ and cobalt chloride $\mathrm{CoCl}_{2} \cdot 6 \mathrm{H}_{2} \mathrm{O}(2: 1)$ were dissolved in $100 \mathrm{~mL}$ of distilled water (DW) then, $1 \mathrm{~g}$ of CMC and finally, $1 \mathrm{~g}$ of HZSM-5 zeolite were added to the solution. Subsequently, $\mathrm{NaOH}$ was added to the resulting suspension for one hour until the solution $\mathrm{pH}$ reached 11 . The reaction container color changed and became black after one hour of stirring. Then, the reaction container was transferred to the microwave and was irradiated by microwave waves. The radiation process was performed in three periods of five minutes with $50 \%$ power of the microwave and 30 seconds with the off mode. The obtained product was a light and black powder that was washed many times using DW and dried in the oven $\left(100{ }^{\circ} \mathrm{C}\right.$ within $24 \mathrm{~h}$ ) (Figure 1). 
(Figure 1)

\subsection{Characterization techniques of $\mathrm{CoFe}_{2} \mathrm{O}_{4} @ \mathrm{CMC} / \mathrm{HZSM}-5$}

Fourier-transform infrared spectroscopy (FTIR) was done using WQF-510 FT-IR spectrometer to determine the adsorbent's functional groups. Characterization of the specimens was done using a field-emission scanning electron microscope-energy dispersive X-ray spectroscopy-Mapping (FESEM-EDS-Mapping) (FE-SEM TESCAN MIRA3) and Transmission electron microscopy (TEM-Philips EM 208S). To find out the presence of the cobalt ferrite crystalline structure in the adsorbent, X-Ray diffraction (XRD) using Philips XPert device (the Netherlands) was employed. The magnetic property of the $\mathrm{CoFe}_{2} \mathrm{O}_{4} @ \mathrm{CMC} / \mathrm{HZSM}-5$ were characterized by VSM (LakeShore Cryotronics-7404) at room temperature. To measure the porosity of the adsorbent surface area, Brunner-Emmett-Taller (BET) method and micrometrics model 021LN2 transfer device was used. Also, thermal gravimetric analysis (TGA) was applied to evaluate the adsorbent thermal resistance (TA Co. Model Q600-USA).

\subsection{Adsorption Method}

The metronidazole adsorption process experiments on the $\mathrm{CoFe}_{2} \mathrm{O}_{4} @ \mathrm{CMC} / \mathrm{HZSM}-5$ nanocomposite were performed in the batch reactor and inside the Erlenmeyer flasks with a volume of $100 \mathrm{~mL}$. At first, metronidazole stock solutions with a concentration of $1000 \mathrm{mg} / \mathrm{L}$ were prepared. Then, in order to investigate the synthesized adsorbent capabilities, $5 \mathrm{~g}$ of adsorbent was added to $50 \mathrm{~mL}$ metronidazole solution $50 \mathrm{mg} / \mathrm{L}$ and was placed in the shaker at $240 \mathrm{rpm}$ for a certain period of time. After this period, by using magnetic separation, the adsorbent was separated from the solution and the metronidazole remaining concentrations were measured.

To recognize and measure the remained concentration of metronidazole, a HPLC device (YL 9100 Waters, USA) was used. Also, for adjusting the device Standard metronidazole with a purity of $99 \%$ was utilized. As well as, deionized water and acetonitrile were applied as mobile phases with volume ratios of 30:70. The utilized column was $\mathrm{C} 18$ with $5 \mu \mathrm{m}$ particles, length of $250 \mathrm{~mm}$, and internal diameter of $4.6 \mathrm{~mm}$. By using a UV absorbance detector within the wavelength of $348 \mathrm{~nm}$ with an injection volume of $20 \mu \mathrm{L}$ and flow rate of $1 \mathrm{~mL} / \mathrm{min}$, the metronidazole remained concentration was measured.

As control samples, the metronidazole samples with similar concentrations without adsorbent were utilized in the all steps of the experiment. The metronidazole initial concentration (50$300 \mathrm{mg} / \mathrm{L}), \mathrm{pH}(3-11)$, amount of adsorbent (0.5 -3 g/L), contact time (0 -300 min), and temperature $(20-50 \mathrm{oC})$ were investigated, to optimize the adsorption conditions and determine the optimal values of each of the adsorption process affecting factors. By solid addition method, the $\mathrm{CoFe}_{2} \mathrm{O}_{4} @ \mathrm{CMC} / \mathrm{HZSM}-5$ point of zero charge $\left(\mathrm{pH}_{\mathrm{pzc}}\right)$ was evaluated. At first, 10 different $\mathrm{pH}(2-11)$ values, $100 \mathrm{~mL}$ of $\mathrm{KCl}$ solution $(0.1 \mathrm{~mol} / \mathrm{L})$ was prepared. Then, $0.01 \mathrm{~g}$ of the magnetic nanobiocomposite was added to each solution. After that, the obtained mixture was stored at room temperature overnight. In the next step, by using $\mathrm{pH}$ meter (Hanna), the initial and final $\mathrm{pH}\left(\mathrm{pH}_{\mathrm{f}}\right)$ values of solutions were determined. To obtain the $\mathrm{pH}_{\mathrm{pzc}}, \Delta \mathrm{pH}=\mathrm{pH}_{\mathrm{f}}-\mathrm{pHi}$ 
and $\mathrm{pH}_{\mathrm{i}}$ plot was drawn. At last, the intersection point of $\Delta \mathrm{pH}=0$ was taken as $\mathrm{pH}_{\mathrm{pzc}}$. By using $\mathrm{NaOH}$ and $\mathrm{HCl} 0.1 \mathrm{~N}$, the solutions $\mathrm{pH}$ was adjusted.

The adsorption experiments were repeated three times in each step and their mean values as the results were used in the calculations. At the end of each experiment, the amount of adsorbed metronidazole on adsorbent $\left(\mathrm{q}_{\mathrm{e}}\right)$ and the percentage of adsorption for each sample was calculated according to equations (Eq. 1) and (Eq. 2), respectively.

$$
\begin{gathered}
q_{e}=\frac{\left(C_{0}-C_{e}\right)}{W} \\
\text { Adsorption }(\%)=\left(\frac{C_{0}-C_{e}}{C_{0}}\right) \times 100
\end{gathered}
$$

Where $\mathrm{C}_{0}(\mathrm{mg} / \mathrm{L})$ is the adsorbate initial concentration (metronidazole), $\mathrm{C}_{\mathrm{e}}(\mathrm{mg} / \mathrm{L})$ is the pollutants equilibrium concentration and $\mathrm{W}$ is the adsorbent mass in the solution volume $(\mathrm{g} / \mathrm{L})$.

\subsection{Adsorption kinetic equations}

The kinetic equations are used to describe the behavior of the adsorbate molecules transfer per time. The adsorption process maybe takes place in several stages with different speeds. In the present study, four kinetic models, Lagergren (pseudo-first order) (Eq. 3), HO (pseudosecond order) (Eq. 4), Elovich model (Eq. 5) and intraparticle diffusion model (Eq. 6) were used.

$$
\begin{aligned}
& \log \left(\mathrm{q}_{\mathrm{e}}-\mathrm{q}_{\mathrm{t}}\right)=\log \mathrm{q}_{\mathrm{e}}-\mathrm{k}_{1} \mathrm{t} / 2.303 \\
& \mathrm{t} / \mathrm{q}_{\mathrm{t}}=1 / \mathrm{k}_{2} \mathrm{q}^{2}+1 / \mathrm{q}_{\mathrm{e}} \mathrm{t} \\
& \mathrm{q}_{\mathrm{t}}=\beta \operatorname{Ln}(\alpha \beta)+\beta \operatorname{Ln} t \\
& \mathrm{q}_{\mathrm{t}}=\mathrm{k}_{\mathrm{i}} \mathrm{t}^{1 / 2}+\mathrm{C}_{\mathrm{i}}
\end{aligned}
$$

$\mathrm{k}_{1}(1 / \mathrm{min})$ and $\mathrm{k}_{2}(\mathrm{mg} / \mathrm{g} \mathrm{min})$ are the $p s e u d o$-first order and pseudo-second order rate constant, respectively. $\mathrm{q}_{\mathrm{e}}(\mathrm{mg} / \mathrm{g})$ and $\mathrm{q}_{\mathrm{t}}(\mathrm{mg} / \mathrm{g})$ are adsorption capacity at equilibrium time and the specified time, respectively and $\alpha(\mathrm{mg} / \mathrm{g} / \mathrm{min})$ and $\beta(\mathrm{g} / \mathrm{mg})$ are also the initial adsorption rate and the surface coating size (or activation energy for chemical adsorption).

\subsection{Adsorption equilibrium equations}

In the adsorption systems design, the equilibrium isotherms are used as important parameters. In fact, they describe relationship between the adsorbent adsorption capacity and adsorbate concentration. In the present study, two common models, the Freundlich (Eq. 7) and Langmuir (Eq. 8) model, have been used for this purpose.

$$
\begin{aligned}
& \log \mathrm{q}_{\mathrm{e}}=\log \mathrm{k}_{\mathrm{f}}+1 / \mathrm{n} \log \mathrm{C}_{\mathrm{e}} \\
& \mathrm{C}_{\mathrm{e}} / \mathrm{q}_{\mathrm{e}}=\mathrm{C}_{\mathrm{e}} / \mathrm{q}_{0}+1 / \mathrm{k}_{1} \mathrm{q}_{0}
\end{aligned}
$$

$\mathrm{k}_{\mathrm{F}}(\mathrm{mg} / \mathrm{g}(\mathrm{L} / \mathrm{mg})$ and $\mathrm{n}$ are the Freundlich constants that $1 / \mathrm{n}$ is intensity of the adsorption process and $\mathrm{k}_{\mathrm{F}}$ is adsorbent adsorption capacity. As well as, $\mathrm{k}_{\mathrm{L}}(\mathrm{L} / \mathrm{mg})$ is the Langmuir constant and $\mathrm{q}_{0}(\mathrm{mg} / \mathrm{g})$ is the maximum amount of adsorbed materials per unit mass of adsorbent. $\mathrm{R}_{\mathrm{L}}$ is 
used to find out the adsorption process desirability in the Langmuir model and determinant by using the following equation:

$$
\mathrm{R}_{\mathrm{L}}=1 / 1+\mathrm{k}_{\mathrm{L}} \mathrm{C}_{0}
$$

\section{Results and Discussion}

\section{1. $\mathrm{CoFe}_{2} \mathrm{O}_{4} @ \mathrm{CMC} / \mathrm{HZSM}-5$ characterization}

\subsubsection{FT-IR spectroscopy}

Comparative FT-IR of CMC, HZSM-5, and $\mathrm{CoFe}_{2} \mathrm{O}_{4} @ \mathrm{CMC} / \mathrm{HZSM}-5$ are demonstrated in Fig.2. In the FT-IR spectrum of carboxymethyl cellulose the wide absorption band at $3424 \mathrm{~cm}^{-}$

${ }^{1}$ belonged to the stretching vibrations of the $\mathrm{OH}$ groups. The absorption band at $2920 \mathrm{~cm}^{-1}$ belonged to the stretching vibrations of the $\mathrm{CH}_{2}$ groups. At 1111 and $1160 \mathrm{~cm}^{-1}$, the $\mathrm{CMC}$ typical vibration was representing the stretching vibration of the $\mathrm{C}-\mathrm{OH}$ groups. The stretching vibrations of the intra molecular hydrogen bond were related to the strong broad band at 3444 $\mathrm{cm}^{-1}$. The band at $2920 \mathrm{~cm}^{-1}$ showed the stretching vibrations of the $\mathrm{C}-\mathrm{H}$ bonds. Moreover, the strong peak at $1648 \mathrm{~cm}^{-1}$ was associated with the stretching vibrations of the carboxyl group, and the absorption bands in the range 1100 to $1150 \mathrm{~cm}^{-1}$ belong to $\mathrm{C}-\mathrm{O}$ stretching vibrations in carboxymethyl cellulose. In the FT-IR spectrum of HZSM-5 the wide absorption band at 3424 $\mathrm{cm}^{-1}$ belonged to the stretching vibrations of the $\mathrm{OH}$ groups. The absorption bands at $799 \mathrm{~cm}-$ 1 (external symmetric stretch), $1102 \mathrm{~cm}^{-1}$ (internal asymmetric stretch), $450 \mathrm{~cm}-1$ (T-O bending vibration of the Si-O and Al-O internal tetrahedral) and $548 \mathrm{~cm}-1$ (double ring vibration) were referred to the HZSM-5 typical characteristics. Also, an asymmetric stretch vibration of the band at $1221 \mathrm{~cm}^{-1}$, was confirmed the HZSM-5 zeolite presence [30]. Meanwhile, this band can used to determine the crystallinity of HZSM-5 zeolites and show the absence of amorphous silica. In the FT-IR of $\mathrm{CoFe}_{2} \mathrm{O}_{4} @ \mathrm{CMC} / \mathrm{HZSM}-5$, the wide absorption band at $3431 \mathrm{~cm}^{-1}$ was associated with the stretching vibrations of hydroxyl groups that overlaid with acidic $\mathrm{OH}$ group of carboxyl group. The absorption band at $1623 \mathrm{~cm}^{-1}$ belonged to the stretching vibrations of the carboxyl group, confirming the presence of carboxymethyl cellulose in the structure of $\mathrm{CoFe}_{2} \mathrm{O}_{4} @ \mathrm{CMC} / \mathrm{HZSM}-5$. Also, Strong absorption bonds at 1349 $\mathrm{cm}^{-1}$ and $1381 \mathrm{~cm}^{-1}$ indicates the presence of HZSM-5 zeolite in the structure of $\mathrm{CoFe}_{2} \mathrm{O}_{4} @ \mathrm{CMC} / \mathrm{HZSM}-5$. In addition, the absorption bands around 400-600 $\mathrm{cm}^{-1}$ in $\mathrm{CoFe}_{2} \mathrm{O}_{4} @ \mathrm{CMC} / \mathrm{HZSM}-5$ is related to vibrations of metal-oxygen groups $(\mathrm{Co}-\mathrm{O}, \mathrm{Fe}-\mathrm{O})$ in the cobalt ferrite and zeolite structure (Si-O, Al-O). 


\subsubsection{FESEM-EDS-Mapping and TEM of $\mathrm{CoFe}_{2} \mathrm{O}_{4} @ \mathrm{CMC} / \mathrm{HZSM}-5$}

The surface morphology of the adsorption material was assessed by FESEM and TEM. The morphological result of $\mathrm{CoFe}_{2} \mathrm{O}_{4} @ \mathrm{CMC} / \mathrm{HZSM}-5$ magnetic nanocomposite is illustrated in Fig. 3a-c. The CMC attendance in the $\mathrm{CoFe}_{2} \mathrm{O}_{4} @ \mathrm{CMC} / \mathrm{HZSM}-5$ synthesis causes the smoothly, uniformly, and loosely aggregated sphere-shaped of magnetic nanocomposite form. The average particle size of $\mathrm{CoFe}_{2} \mathrm{O}_{4} @ \mathrm{CMC} / \mathrm{HZSM}-5$ is about $27 \mathrm{~nm}$.

(Figure 3)

The synthesized $\mathrm{CoFe}_{2} \mathrm{O}_{4} @ \mathrm{CMC} / \mathrm{HZSM}-5$ magnetic nanoadsorbent purity and chemical structure were evaluated by EDS analysis (Fig. 4). The results obtained $46.44 \% \mathrm{O}, 26.82 \% \mathrm{Fe}$, $14.16 \% \mathrm{Co}, 8.56 \% \mathrm{C}, 3.88 \% \mathrm{Si}$, and $0.15 \% \mathrm{Al}$ which are following the expected values.

(Figure 4)

Mapping is the observation of how the elements are distributed at high resolution. It was used to investigate the $\mathrm{CoFe}_{2} \mathrm{O}_{4} @ \mathrm{CMC} / \mathrm{HZSM}-5$ elements distribution. Based on the obtained results which is showed in Fig. 5, $\mathrm{Al}, \mathrm{Si}, \mathrm{Co}, \mathrm{Fe}, \mathrm{O}$, and $\mathrm{C}$ had a homogeneous distribution that indicates high uniformity of the synthesized $\mathrm{CoFe}_{2} \mathrm{O}_{4} @ \mathrm{CMC} / \mathrm{HZSM}-5$ (Fig. 5).

\section{(Figure 5)}

\subsubsection{XRD}

The XRD patterns were prepared separately from CMC, HZSM-5, $\mathrm{CoFe}_{2} \mathrm{O}_{4}$, and $\mathrm{CoFe}_{2} \mathrm{O}_{4} @ \mathrm{CMC} @ \mathrm{HZSM}-5$ and were compared with each other (Figure 6).

In the CMC XRD pattern, the index peak can be seen in the area of $18.28^{\circ} .23 .15^{\circ}$ and $24.06^{\circ}$ peaks are belong to HZSM-5 and the values which are seen in $2 \theta=30.26^{\circ}, 35.70^{\circ}$, $43.35^{\circ}, 53.74^{\circ}, 57.29^{\circ}$, and $62.81^{\circ}$ are related to cobalt ferrite. The XRD results of $\mathrm{CoFe}_{2} \mathrm{O}_{4} @ \mathrm{CMC} / \mathrm{HZSM}-5$ magnetic nanocomposite in the range from 10 to 80 degrees $(2 \theta=$ $10^{\circ}-80^{\circ}$ ) are depicted in figure 6 . The sharp diffractions in regions $18.28^{\circ}, 23.15^{\circ}, 24.06^{\circ}$, $30.26^{\circ}, 35.70^{\circ}, 43.35^{\circ}, 53.74^{\circ}, 57.29^{\circ}$, and $62.81^{\circ}$ indicated the crystalline structure in the spinel shape, which was consistent with the Joint Committee on Powder Diffraction Standards (no. 96-900-5813). The presence of sharp and strong peaks in this pattern and comparison of peak locations with reference data indicated the crystalline structure of cobalt ferrite with complete crystallization that has preserved the crystalline structure of $\mathrm{CoFe}_{2} \mathrm{O}_{4} @ \mathrm{CMC} / \mathrm{HZSM}$ 5 , after being composite with carboxymethylcellulose and zeolite.

(Figure 6)

\subsubsection{VSM}

The results of vibrating-sample magnetometer (VSM) analysis of $\mathrm{CoFe}_{2} \mathrm{O}_{4} @ \mathrm{CMC} / \mathrm{HZSM}-5$ are demonstrated in figure 7. Magnetic coercive force (Hc), saturation magnetization (Ms), and 
remnant magnetization $(\mathrm{Mr})$ were equal to $0.73 \mathrm{Qe}, 41.36 \mathrm{emu} / \mathrm{g}$, and $50 \mathrm{emu} / \mathrm{g}$, in that order. The results revealed that the $\mathrm{CoFe}_{2} \mathrm{O}_{4} @ \mathrm{CMC} / \mathrm{HZSM}-5$ magnetic nanocomposite had a ferromagnetic effect with elevated saturation magnetization and high magnetic coercive force. It could be quickly separated and retrieved from the reaction container using a magnet and could be reused in subsequent periods.

\section{(Figure 7)}

\subsubsection{BET}

The obtained information from the BET test showed that surface area, pore volume, and pore size equaled $235.21 \mathrm{~m}^{2} / \mathrm{g}, 0.207 \mathrm{~cm}^{3} / \mathrm{g}$, and $3.52 \mathrm{~nm}$, respectively. The BET analysis results of $\mathrm{CoFe}_{2} \mathrm{O}_{4} @ \mathrm{CMC} / \mathrm{HZSM}-5$ magnetic nanocomposite can be considered as a mesoporous material

\subsubsection{TGA}

TGA was used to evaluate CoFe2O4@CMC/HZSM-5 thermal decomposition. The results are demonstrated in Fig. 8. TGA analysis was done in the room temperature to $600{ }^{\circ} \mathrm{C}$, to evaluate the $\mathrm{CoFe}_{2} \mathrm{O}_{4} @ \mathrm{CMC} / \mathrm{HZSM}-5$ nanocomposite thermal stability (Fig. 8). The mass loss was happened in the temperature range of $20-100{ }^{\circ} \mathrm{C}$ which is linked with the adsorbed water loss. Due to the breakdown of CMC glycosidic bonds and also, its decomposition into lower fatty acids, the weight loss was reported at 100-600 ${ }^{\circ} \mathrm{C}$. According to the results, the adsorbent total weight loss was seen $10.18 \%$ until $600{ }^{\circ} \mathrm{C}$ which shows the $\mathrm{CoFe}_{2} \mathrm{O}_{4} @ \mathrm{CMC} / \mathrm{HZSM}-5$ magnetic nanocomposite high thermal stability

\section{(Figure 8)}

\subsection{Adsorption experiment optimization}

\subsection{1. pH effect}

Environmental acidity where the adsorption process takes place is largely effective in adsorption and removal efficiency. A part of this issue is related to hydrogen ions $\left(\mathrm{H}^{+}\right)$, which adsorbed on the adsorbent surface. The contaminant adsorption on the adsorbent surface leads to reduce the positive ions adsorption. The other part refers to the $\mathrm{pH}$ effect, which is effective in some compounds ionization. In order to evaluate effect of $\mathrm{pH}$ changes on the metronidazole removal by the $\mathrm{CoFe}_{2} \mathrm{O}_{4} @ \mathrm{CMC} / \mathrm{HZSM}-5$ nanocomposite, $50 \mathrm{~mL}$ solution containing $2 \mathrm{~g} / \mathrm{L}$ adsorbent and the metronidazole initial concentrations $50 \mathrm{mg} / \mathrm{L}$ were used. The results are presented in figure 9. The obtained results showed that the pollutant removal efficiency increased with increasing $\mathrm{pH}$ from 2 to 6 and decreased at $\mathrm{pH}$ values more than 6 . The highest metronidazole removal efficiency took place at $\mathrm{pH} 6$ and was equal to $94 \%$.

(Figure 9) 
The effect of $\mathrm{pH}$ could be explain in terms of the adsorbent $\mathrm{pHzpc}$ and $\mathrm{MNZ} \mathrm{pKa} \cdot \mathrm{pH}_{\mathrm{zpc}}$ of $\mathrm{CoFe}_{2} \mathrm{O}_{4} @ \mathrm{CMC} / \mathrm{HZSM}-5$ was determined by solid addition method and was obtained 6.8. At pHs less than pHzpc, the $\mathrm{CoFe}_{2} \mathrm{O}_{4} @ \mathrm{CMC} / \mathrm{HZSM}-5$ surface charge was positive; thereby the chance of MNZ ions adsorption increased. At pHs more than $\mathrm{pHzpc}$, the surface charge of the $\mathrm{CoFe}_{2} \mathrm{O}_{4} @ \mathrm{CMC} / \mathrm{HZSM}-5$ was negative. As a result, the repulsion between the interfaces increased in the solution [54]. On the other hand, high $\mathrm{pH}$ leads to higher concentrations production of ${ }^{-} \mathrm{OH}$ in the solution and also, inhibit of $\mathrm{MNZ}$ ions scattered, thereby the chance of MNZ adsorption decreased [54]. Therefore, $\mathrm{pH} 6$ was selected as the optimum $\mathrm{pH}$.

\subsubsection{Equilibrium time}

The equilibrium time for the metronidazole removal process was evaluated over a period of $300 \mathrm{~min}$, metronidazole initial concentrations $50 \mathrm{mg} / \mathrm{L}$ and at the optimum $\mathrm{pH}$ (Figure 10). The above figure shows that the adsorbates adsorption rate in the initial times was much higher than the next times or in other words, by increasing contact time, the adsorption capacity increased. But after 60 minutes, no significant changes were observed in adsorption capacity. For example, by increasing the contact time from 60 to 300 minutes, the metronidazole adsorption capacity increased from 22.5 and $23.5 \mathrm{mg} / \mathrm{g}$ to 22.6 and $23.7 \mathrm{mg} / \mathrm{g}$, respectively. These results indicate that the metronidazole removal process is balanced in 60 minutes and therefore, this time was considered as the equilibrium time for the adsorption experiments continuation. Significant increase in adsorption capacity at the beginning of the contact time (Figure 10) could be relate to the presence of many active and unsaturated sites on the $\mathrm{CoFe}_{2} \mathrm{O}_{4} @ \mathrm{CMC} / \mathrm{HZSM}-5$ external surfaces. However, by increasing contact time, the adsorption capacity is stabilized. The stabilization of the adsorption capacity or reaching the equilibrium point in more than 60 minutes may be due to the active sites occupation on the adsorbent surface or the adsorbent capacity completion. In general, by increasing contact time, the adsorbat ions access to the empty active sites on the adsorbent surface is reduced and eventually these sites are saturated and the process reaches equilibrium.

(Figure 10)

\subsubsection{Influence of different concentrations of adsorbent and adsorbate}

Figures $11 \mathrm{a}$ and $\mathrm{b}$ are showing the results of the adsorbent $\left(\mathrm{CoFe}_{2} \mathrm{O}_{4} @ \mathrm{CMC} / \mathrm{HZSM}-5\right)$ and adsorbate different amounts concentration (metronidazole) effects under optimal conditions, respectively. As shown in figure 11a, by increasing the amount of adsorbent from 0.5 to $3 \mathrm{~g} / \mathrm{L}$, the metronidazole adsorption increased from 73 to $94 \%$. Therefore, considering that in the amount of $2 \mathrm{~g} / \mathrm{L}$ of adsorbent, the removal efficiency was $94 \%$, this value was selected as the adsorbent optimal dose. But, in figure $11 \mathrm{~b}$, it can be seen that the changes in the initial concentration had a negative effect on the adsorption rate, such that by increasing the metronidazole initial concentration from 50 to $300 \mathrm{mg} / \mathrm{L}$, the removal efficiency decreased from 95 to $59 \%$, respectively. The removal efficiency increasing in the study of the amount of adsorbent changes (Figure 11a) maybe due to the adsorbent surface increasing or increase the access of the adsorbate molecules to the pores on the magnetic nanocomposite surface. On the other hand, figure $11 \mathrm{~b}$ shows that by increasing the metronidazole initial concentrations, the 
removal efficiency decreased. Probably, constant numbers of active sites on the adsorbent against the increasing in the number of adsorbate molecules or the saturation of the adsorbent surface at high concentrations of contaminants was the main reason for the decrease in removal efficiency by increasing the initial contaminant concentration.

\section{(Figure 11)}

\subsubsection{Adsorption kinetic}

The kinetic parameters amounts of the metronidazole removal process are presented in table 1. The computational adsorption capacity values ( $\mathrm{q}_{\mathrm{e}}$, cal) for pseudo-first order and pseudosecond order models were obtained 22 and $24.2 \mathrm{mg} / \mathrm{g}$, respectively. In addition, the experimental adsorption capacity ( $\mathrm{q}_{\mathrm{e}}$, exp) from the obtained experiments was $23.5 \mathrm{mg} / \mathrm{g}$. The lowest correlation coefficient was obtained for the Elovich equation and intraparticle diffusion model. The curves of the studied metronidazole removal kinetic models compared with the obtained experimental data from the experiments are presented in figure 12 . The results of the metronidazole removal kinetic study by $\mathrm{CoFe}_{2} \mathrm{O}_{4} @ \mathrm{CMC} / \mathrm{HZSM}-5$, according to the table 1 showed that based on the calculated correlation coefficients, the adsorption behavior per unit time follows pseudo-first order and pseudo-second order models. However, it is observed that the metronidazole correlation coefficient in the pseudo-second order kinetic was 0.997 that is higher than the obtained values for the pseudo-first order kinetic model. Therefore, it can be admitted that the model in the present study has more validity than the other three models. Tang et al. (2012) [55] in the study on aniline and caprolactam simultaneous adsorption by the granular activated carbon found that the pollutants adsorption behavior per unit time follows the pseudo-second order model. As well as, valderrama in the study of the phenol and aniline simultaneous adsorption by the activated carbon, reported both pseudo-first order and pseudosecond order kinetic models as suitable models for the data describing. According to table 1, the boundary layer thickness values $(\mathrm{Ci})$ in the intraparticle diffusion model were not equal to zero, that indicates the intraparticle diffusion model was not the only controlling step of the process and perhaps the external adsorption mechanism may also had been effective as a control factor in the adsorption process.

\section{(Figure 12)}

\section{(Table 1)}

\subsubsection{Adsorption isotherm}

Table 2 shows the Langmuir and Freundlich equilibrium isotherms values for the metronidazole adsorption in the temperature range of $20-50{ }^{\circ} \mathrm{C}$. The above table indicates that the correlation coefficient in Langmuir and Freundlich models is $\mathrm{R}^{2}>0.97$. In this research, the maximum adsorption capacity ( $\mathrm{q}_{0}$ ) based on the Langmuir model at $50{ }^{\circ} \mathrm{C}$ was obtained 206.6 $\mathrm{mg} / \mathrm{g}$. In figure 13, the curves of the Langmuir and Freundlich equilibrium isotherm models with experimental data were compered. In the metronidazole adsorption isotherms examination (Table 2) it can be seen that the obtained regression coefficients in Freundlich and Langmuir models for all three temperatures are more than 0.97. In fact, these results indicate that both 
models are suitable for describing experimental test data. In the above table, it is also noteworthy that the pollutant maximum adsorption capacity values based on the Langmuir isotherm model for the increased by increasing the solution temperature. For example, by increasing temperature from 20 to $50{ }^{\circ} \mathrm{C}$, the maximum adsorption capacity increased from 201.1 to $206.6 \mathrm{mg} / \mathrm{g}$. This trend indicates that the increase in the temperature had a positive effect on the adsorption capacity. In addition, the Langmuir model $\mathrm{R}_{\mathrm{L}}$ values of the adsorbat were studied at all temperatures and was obtained less than one $\left(1<\mathrm{R}_{\mathrm{L}}<0\right)$. Therefore, it is concluded that the $\mathrm{CoFe}_{2} \mathrm{O}_{4} @ \mathrm{CMC} / \mathrm{HZSM}-5$ had high efficiency in the metronidazole removal. Table 2 also shows that the $1 / n$ values related to the Freundlich isotherm were less than one in all three temperatures, which indicate the high adsorption of the pollutant.

(Figure 13)

(Table 2)

\subsubsection{Adsorption thermodynamic}

The results of measuring $\mathrm{Lnk}_{\mathrm{c}}$ values versus temperature changes based on the Vant Hoff curve to determine the values of the metronidazole adsorption process thermodynamic parameters are shown in figure 14. Also, table 3 presents the obtained values of the thermodynamic parameters. Table 3 demonstrates that the standard enthalpy $\left(\Delta \mathrm{H}^{\circ}\right)$ and standard entropy values $\left(\Delta \mathrm{S}^{\circ}\right)$ are positive and the standard gibbs free energy $\left(\Delta \mathrm{G}^{\circ}\right)$ is negative. Due to the presented results in table 3 , it can be seen that the standard enthalpy values $\left(\Delta \mathrm{H}^{\circ}\right)$ is positive, which indicates that the metronidazole removal process is endothermic and adsorption at the higher temperatures is desirable. Standard entropy value $\left(\Delta S^{\circ}\right)$ was obtained positive which indicates the adsorbent tendency to adsorb the adsorbate and increase the efficiency by increasing the temperature in the solid-liquid interface during the adsorption process. Nevertheless, the Gibbs free energy values $\left(\Delta \mathrm{G}^{\circ}\right)$ were negative in all three studied temperatures. These negative values indicate that the metronidazole removal by $\mathrm{CoFe}_{2} \mathrm{O}_{4} @ \mathrm{CMC} / \mathrm{HZSM}-5$ is spontaneous reaction. Since the metronidazole $\Delta \mathrm{H}^{\mathrm{o}}$ value was less than $40 \mathrm{~kJ} / \mathrm{mol}$, it can be concluded that the adsorption process had a physical mechanism. In addition, the $\Delta \mathrm{G}^{\mathrm{o}}$ obtained values at all the studied temperatures were less than $-20 \mathrm{~kJ} / \mathrm{mol}$, which confirm that the adsorption process was a physical type.

(Figure 14)

(Table 3)

\subsubsection{Effect of CMC on the removal efficiency}

The obtained metronidazole removal efficiencies by $\mathrm{CoFe}_{2} \mathrm{O}_{4}, \mathrm{CMC}$, HZSM-5, and $\mathrm{CoFe}_{2} \mathrm{O}_{4} @ \mathrm{CMC} / \mathrm{HZSM}-5$ were compared (Figure 15). Based on the findings, the removal efficiencies by using HZSM-5, CMC, $\mathrm{CoFe}_{2} \mathrm{O}_{4}$, and $\mathrm{CoFe}_{2} \mathrm{O}_{4} @ \mathrm{CMC} / \mathrm{HZSM}-5$ were 75\%, $83 \%, 87 \%$, and 94\%, respectively. $\mathrm{CoFe}_{2} \mathrm{O}_{4} @ \mathrm{CMC} / \mathrm{HZSM}-5$ showed a significantly higher 
removal efficiency than the other adsorbents after $60 \mathrm{~min}$ contact time. It can be concluded that $\mathrm{CoFe}_{2} \mathrm{O}_{4} @ \mathrm{CMC} / \mathrm{HZSM}-5$ composed of carboxymethylcellulose as a polysaccharide with high carboxyl and hydroxyl groups. Consequently, the presence of these functional groups causes the interaction of electrostatic attraction between the adsorbent surface and metronidazole [56, 57]. As well as, CMC plays an important role in improving the structural properties of $\mathrm{CoFe}_{2} \mathrm{O}_{4} @ \mathrm{CMC} / \mathrm{HZSM}-5$ magnetic nanocomposite. The presence of CMC during the preparation of $\mathrm{CoFe}_{2} \mathrm{O}_{4} @ \mathrm{CMC} / \mathrm{HZSM}-5$, increases the adsorbent surface area and provides more active sites for the metronidazole removal.

\section{(Figure 15)}

\subsection{Mechanism}

The metronidazole adsorption efficiency depends upon to the surface groups of the magnetic nanoadsorbent protonation and non-protonation status. The $\mathrm{pH}$ of solution is one of the most important parameters which can qualifies the $\mathrm{CoFe}_{2} \mathrm{O}_{4} @ \mathrm{CMC} / \mathrm{HZSM}-5$ charge and has effect on the interaction between metronidazole molecules. To determine the amount of $\mathrm{CoFe}_{2} \mathrm{O}_{4} @ \mathrm{CMC} / \mathrm{HZSM}-5$ magnetic nanoadsorbent surface charge and its type, at different $\mathrm{pHs}, \mathrm{pHzPC}$ was investigated. The synthesized magnetic nanoadsorbent surface charge was negative at pHs more than 6.8, although at the lower pHs, the adsorbent surface charge was positive. Metronidazole due to its electron-rich aromatic rings has desire to adsorb on the adsorbent positively charged surface. Metronidazole $\mathrm{pK}_{\mathrm{a}}$ was equal to 2.55 , it created an electrostatic gravity energy which leaded to more metronidazole removal by the $\mathrm{CoFe}_{2} \mathrm{O}_{4} @ \mathrm{CMC} / \mathrm{HZSM}-5$. The amount of metronidazole molecules which have negatively charged increased slowly by increasing the $\mathrm{pH}$ value in the solution [58]. With attention to the $\mathrm{CoFe}_{2} \mathrm{O}_{4} @ \mathrm{CMC} / \mathrm{HZSM}-5$ adsorption behavior at different $\mathrm{pH}$ values and its characteristics, the main mechanism for the metronidazole removal perhaps makes a complex between metronidazole anions and the adsorbent surface. The metronidazole removal mechanism by $\mathrm{CoFe}_{2} \mathrm{O}_{4} @ \mathrm{CMC} / \mathrm{HZSM}-5$ is shown in figure 16.

\section{(Figure 16)}

\subsection{Regeneration, reusability and chemical stability of $\mathrm{CoFe}_{2} \mathrm{O}_{4} @ \mathrm{CMC} / \mathrm{HZSM}-5$}

Regeneration and recycling are two important items in the adsorbent functional. After metronidazole removal, $\mathrm{CoFe}_{2} \mathrm{O}_{4} @ \mathrm{CMC} / \mathrm{HZSM}-5$ magnetic nanocomposite, were recycled for six consecutive adsorption runs. To regenerate $\mathrm{CoFe}_{2} \mathrm{O}_{4} @ \mathrm{CMC} / \mathrm{HZSM}-5$, this magnetic nanocomposite, following each cycle, was separated from the solution by a magnet and was washed with $\mathrm{HCl} / \mathrm{DW}$ for several times. At last, the magnetic nanoadsorbent was dried in an oven at $60^{\circ} \mathrm{C}$. The dried magnetic nanoadsorbent was reused to start the next cycle of metronidazole adsorption. Base on the figure $17 \mathrm{a}$, the metronidazole removal efficiency after six recycling cycles, reduced from $94 \%$ to $86 \%$. On the other hand, the pollutant adsorption percentage from the first to last cycles demonstrated solely $12 \%$ reduction that can be because of the magnetic nanocomposite mass over the several cycles. Based on the obtained results 
from the $\mathrm{CoFe}_{2} \mathrm{O}_{4} @ \mathrm{CMC} / \mathrm{HZSM}-5$ regeneration, a slight decrease in the removal efficiency can be related to the occupation of active adsorbent sites by the metronidazole and decreasing in the amount of $\mathrm{CoFe}_{2} \mathrm{O}_{4} @ \mathrm{CMC} / \mathrm{HZSM}-5$ during the washing and regeneration processes. Therefore, due to the high recyclability of $\mathrm{CoFe}_{2} \mathrm{O}_{4} @ \mathrm{CMC} / \mathrm{HZSM}-5$, its application is economical in terms of operational costs. The $\mathrm{CoFe}_{2} \mathrm{O}_{4} @ \mathrm{CMC} / \mathrm{HZSM}-5$ stability was investigated by FESEM (Fig. 17b) band XRD (Fig. 17c) analysis. Indicates the $\mathrm{CoFe}_{2} \mathrm{O}_{4} @ \mathrm{CMC} / \mathrm{HZSM}-5 \mathrm{XRD}$ pattern after the sixth run of the magnetic nanoadsorbent recycling. The XRD analysis demonstrated that the $\mathrm{CoFe}_{2} \mathrm{O}_{4} @ \mathrm{CMC} / \mathrm{HZSM}-5$ magnetic nanoadsorbent, did not have obvious changes except in the intensity of diffraction peaks following the sixth run of magnetic nanoadsorbent recycling. Also, the morphology of the magnetic nanadosorbent has been preserved and did not have significantly change. The results showed the chemical stability of the magnetic nanoadsorbent after sixth run recycling.

(Figure 17)

\subsection{Removal of metronidazole from real wastewater}

The optimal conditions were determined. After that, the experiment was done on the campus wastewater at Kerman University of Medical Sciences. The real sample physicochemical characterizations were obtained and its specifications were achieved COD (415 mg L-1), BOD (247 mg L $\left.{ }^{-1}\right)$, TSS (20 mg L $\left.{ }^{-1}\right)$, TDS (545 mg L-1), TKN (78 $\left.\mathrm{mg} \mathrm{L}^{-1}\right)$, Phosphate $\left(16.7 \mathrm{mg} \mathrm{L}^{-1}\right)$, Nitrate $\left(16.5 \mathrm{mg} \mathrm{L}^{-1}\right)$, Sulfate $\left(352 \mathrm{mg} \mathrm{L}^{-1}\right)$, and Metronidazole $\left(45 \mathrm{mg} \mathrm{L}^{-1}\right)$. The metronidazole maximum removal efficiency was $85 \%$ in the adsorbent $2 \mathrm{~g} / \mathrm{L}, \mathrm{pH}$ 6, initial metronidazole concentration $45 \mathrm{mg} / \mathrm{L}$ and contact time $60 \mathrm{~min}$. Due to the presence of cations, anions, TDS and TSS in the real wastewater, the metronidazole removal efficiency decreased.

The performance of $\mathrm{CoFe}_{2} \mathrm{O}_{4} @ \mathrm{CMC} / \mathrm{HZSM}-5$ magnetic nanoadsorbent in the pharmaceutical compounds removal was compared with the other magnetic nanoadsorbent. It can be concluded that $\mathrm{CoFe}_{2} \mathrm{O}_{4} @ \mathrm{CMC} / \mathrm{HZSM}-5$ magnetic nanoadsorbent in comparison with the other magnetic nanoadsorbent, had a higher pollutants removal efficiency in a shorter time, a lower dose of adsorbent and at the relatively neutral pH. Also, $\mathrm{CoFe}_{2} \mathrm{O}_{4} @ \mathrm{CMC} / \mathrm{HZSM}-5$ magnetic nanoadsorbent had a high specific surface area and the higher adsorption capacity.

\section{Conclusion}

The results of the present study showed that the using magnetic nanoparticles with the aim of magnetic property induction in widely used adsorbents, especially CMC, is a simple, fast and practical method due to the lack of problems belong to separation, filtration and centrifugation. CMC plays an important role in improving the structural properties of $\mathrm{CoFe}_{2} \mathrm{O}_{4} @ \mathrm{CMC} / \mathrm{HZSM}-5$ magnetic nanocomposite. The presence of CMC during the preparation of this nanocomposite, increased the adsorbent surface area and provided more active sites for the metronidazole removal. The optimal conditions in the present study were obtained at $\mathrm{pH} 6$, contact time $60 \mathrm{~min}$, adsorbent $2 \mathrm{~g} / \mathrm{L}$ and temperature $20{ }^{\circ} \mathrm{C}$. The metronidazole removal efficiency and maximum adsorption capacity based on the Langmuir 
equilibrium model were obtained 94 and $206.6 \mathrm{mg} / \mathrm{g}$, respectively. The adsorption efficiency increased by increasing contact time, the adsorbent amount and solution temperature, while the metronidazole initial concentrations had an indirect effect on the adsorption efficiency. Magnetized nanocomposite due to its high specific surface area can be used as an effective and cost-effective adsorbent to remove environmental pollutants from water sources. Therefore it is expected it use for quickly and easily separate different types of adsorbents from solutions. According to the obtained results, it could be concluded that the adsorption process was endothermic and had a physical mechanism. Finally, the chemical stability and reusability of the synthesized $\mathrm{CoFe}_{2} \mathrm{O}_{4} @ \mathrm{CMC} / \mathrm{HZSM}-5$ magnetic nanoadsorbent were evaluated in the metronidazole removal. The achieved findings demonstrated that following six adsorption runs, he adsorbent chemical structure had no change and the magnetic nanoadsorbent efficiency in the removal process had a slight decrease.

\section{Credit Author Statement}

Alireza Nasiri: Project administration, Supervision, Mohammad Reza Heidari: Investigation, Writing original draft. Ghazal Yazdanpanah: Investigation, Validation, Writing, review \& editing.

\section{Acknowledgments}

We would like to thank the Environmental Health Engineering Research Center of Kerman University of Medical Sciences for their financial support. This research with Reg. No. 99000674 was approved by ethical committee of Kerman University of Medical Sciences. The Ethic approval Code is IR.KMU.REC.1399.578.

\section{References}

[1] P. Wang, D. Wu, X. You, Y. Su, B. Xie, Antibiotic and metal resistance genes are closely linked with nitrogen-processing functions in municipal solid waste landfills, J. Hazard. Mater. 403 (2021). https://doi.org/10.1016/j.jhazmat.2020.123689.

[2] H. Guo, Z. Li, L. Xiang, N. Jiang, Y. Zhang, H. Wang, J. Li, Efficient removal of antibiotic thiamphenicol by pulsed discharge plasma coupled with complex catalysis using graphene-WO3-Fe3O4 nanocomposites, J. Hazard. Mater. 403 (2021). https://doi.org/10.1016/j.jhazmat.2020.123673.

[3] M.J. Stephen, Disadvantages of set length antibiotic treatment for pulmonary exacerbation, Lancet Respir. Med. 6 (2018) 573-575. https://doi.org/10.1016/S22132600(18)30266-2.

[4] D.H. Carrales-Alvarado, I. Rodríguez-Ramos, R. Leyva-Ramos, E. Mendoza-Mendoza, D.E. Villela-Martínez, Effect of surface area and physical-chemical properties of graphite and graphene-based materials on their adsorption capacity towards metronidazole and trimethoprim antibiotics in aqueous solution, Chem. Eng. J. 402 (2020). https://doi.org/10.1016/j.cej.2020.126155.

[5] P. Grenni, V. Ancona, A. Barra Caracciolo, Ecological effects of antibiotics on natural 
ecosystems: A review, Microchem. J. $136 \quad$ (2018) 25-39. https://doi.org/https://doi.org/10.1016/j.microc.2017.02.006.

[6] W. Wang, X. Li, S. Yuan, J. Sun, S. Zheng, Effect of resin charged functional group, porosity, and chemical matrix on the long-term pharmaceutical removal mechanism by conventional ion exchange resins, Chemosphere. 160 (2016) 71-79. https://doi.org/10.1016/j.chemosphere.2016.06.073.

[7] D. Mousel, D. Bastian, J. Firk, L. Palmowski, J. Pinnekamp, Removal of pharmaceuticals from wastewater of health care facilities, Sci. Total Environ. 751 (2021). https://doi.org/10.1016/j.scitotenv.2020.141310.

[8] T.I.A. Gouveia, A.M.T. Silva, A.R. Ribeiro, A. Alves, M.S.F. Santos, Liquid-liquid extraction as a simple tool to quickly quantify fourteen cytostatics in urban wastewaters and access their impact in aquatic biota, Sci. Total Environ. 740 (2020). https://doi.org/10.1016/j.scitotenv.2020.139995.

[9] B.L. Phoon, C.C. Ong, M.S. Mohamed Saheed, P.-L. Show, J.-S. Chang, T.C. Ling, S.S. Lam, J.C. Juan, Conventional and emerging technologies for removal of antibiotics from

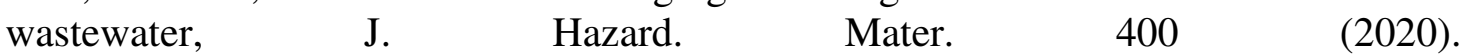
https://doi.org/10.1016/j.jhazmat.2020.122961.

[10] M.L. Ferrey, M. Coreen Hamilton, W.J. Backe, K.E. Anderson, Pharmaceuticals and other anthropogenic chemicals in atmospheric particulates and precipitation, Sci. Total Environ. 612 (2018) 1488-1497. https://doi.org/10.1016/j.scitotenv.2017.06.201.

[11] J.-L. Ding, R. Liu, W. Zheng, W.-J. Yu, Z.-X. Ye, L.-J. Chen, Y.-M. Zhang, Method for simultaneous determination of 11 veterinary antibiotics in piggery wastewater and sludge and its application in biological treatment, Huanjing Kexue/Environmental Sci. 36 (2015) 3918-3925. https://doi.org/10.13227/j.hjkx.2015.10.049.

[12] J.D. García-Espinoza, M. Zolfaghari, P. Mijaylova Nacheva, Synergistic effect between ultraviolet irradiation and electrochemical oxidation for removal of humic acids and $\begin{array}{llllll}\text { pharmaceuticals, Water } & \text { Environ. J. } 34 \quad \text { (2020) }\end{array}$ https://doi.org/10.1111/wej.12456.

[13] G. Mahdizadeh, H; Nasiri, A; Amiri Gharaghani, M; Yazdanpanah, Hybrid UV/COP Advanced Oxidation Process Using $\mathrm{ZnO}$ as a Catalyst Immobilized on a Stone Surface for degradation of Acid Red 18 Dye, MethodsX. 7(2020) 101118. https://doi.org/10.1016/j.mex.2020.101118

[14] G. Malakootian, M; Smith, A; Gharaghani, MA; Mahdizadeh, H; Nasiri, A; Yazdanpanah, Decoloration of textile Acid Red 18 dye by hybrid UV/COP advanced oxidation process using $\mathrm{ZnO}$ as a catalyst immobilized on a stone surface, Desalin. WATER Treat. 182 (2020) 385-394. https://doi.org/10.5004/dwt.2020.25216.

[15] K. Rajabizadeh, G. Yazdanpanah, S. Dowlatshahi, M. Malakootian, Photooxidation Process Efficiency (UV/O3) for P-nitroaniline Removal from Aqueous Solutions, Ozone Sci. Eng. (2019). https://doi.org/10.1080/01919512.2019.1679614.

[16] S.-M. Germán, R.-M. Gabriela, S.-C. Dora, R. Rubí, N. Reyna, Advanced Oxidation Processes: Ozonation and Fenton Processes Applied to the Removal of Pharmaceuticals, Handb. Environ. Chem. 66 (2019) 119-142. https://doi.org/10.1007/698_2017_166.

[17] E.O. Ezugbe, S. Rathilal, Membrane technologies in wastewater treatment: A review, 
Membranes (Basel). 10 (2020). https://doi.org/10.3390/membranes10050089.

[18] P. Rajasulochana, V. Preethy, Comparison on efficiency of various techniques in treatment of waste and sewage water - A comprehensive review, Resour. Technol. 2 (2016) 175-184. https://doi.org/https://doi.org/10.1016/j.reffit.2016.09.004.

[19] S. De Gisi, G. Lofrano, M. Grassi, M. Notarnicola, Characteristics and adsorption capacities of low-cost sorbents for wastewater treatment: A review, Sustain. Mater. Technol. 9 (2016) 10-40. https://doi.org/https://doi.org/10.1016/j.susmat.2016.06.002.

[20] P.K. Yeow, S.W. Wong, T. Hadibarata, Removal of azo and anthraquinone dye by plant biomass as adsorbent - a review, Biointerface Res. Appl. Chem. 11 (2021) 8218-8232. https://doi.org/10.33263/BRIAC111.82188232.

[21] D.S. Dlamini, J.M. Tesha, G.D. Vilakati, B.B. Mamba, A.K. Mishra, J.M. Thwala, J. Li, A critical review of selected membrane- and powder-based adsorbents for water treatment: Sustainability and effectiveness, J. Clean. Prod. 277 (2020). https://doi.org/10.1016/j.jclepro.2020.123497.

[22] S. Kulkarni, Synthesis, characterization and performance of low-cost unconventional adsorbents derived from waste materials, Biointerface Res. Appl. Chem. 10 (2020) 7243-7256. https://doi.org/10.33263/BRIAC106.72437256.

[23] C. Duan, T. Ma, J. Wang, Y. Zhou, Removal of heavy metals from aqueous solution using carbon-based adsorbents: A review, J. Water Process Eng. 37 (2020). https://doi.org/10.1016/j.jwpe.2020.101339.

[24] Y. Deng, Low-cost adsorbents for urban stormwater pollution control, Front. Environ. Sci. Eng. 14 (2020). https://doi.org/10.1007/s11783-020-1262-9.

[25] N. Amirmahani, M. Rashidi, N.O. Mahmoodi, Synthetic application of gold complexes on magnetic supports, Appl. Organomet. Chem. 34 (2020). https://doi.org/10.1002/aoc.5626.

[26] N. Amirmahani, N.O. Mahmoodi, M. Bahramnejad, N. Seyedi, Recent developments of metallic nanoparticles and their catalytic activity in organic reactions, J. Chinese Chem. Soc. (2020). https://doi.org/10.1002/jccs.201900534.

[27] N. Amirmahani, N.O. Mahmoodi, M. Malakootian, A. Pardakhty, N. Seyedi, Pd nanoparticles supported on $\mathrm{Fe} 3 \mathrm{O} 4 @ \mathrm{SiO} 2-\mathrm{Schiff}$ base as an efficient magnetically recoverable nanocatalyst for Suzuki-Miyaura coupling reaction, Res. Chem. Intermed. (2020). https://doi.org/10.1007/s11164-020-04223-7.

[28] N. Amirmahani, H. Mahdizadeh, M. Malakootian, A. Pardakhty, N.O. Mahmoodi, Evaluating Nanoparticles Decorated on Fe3O4@SiO2-Schiff Base (Fe3O4@SiO2APTMS-HBA) in Adsorption of Ciprofloxacin from Aqueous Environments, J. Inorg. Organomet. Polym. Mater. (2020). https://doi.org/10.1007/s10904-020-01499-5.

[29] A. Rebekah, G. Bharath, M. Naushad, C. Viswanathan, N. Ponpandian, Magnetic graphene/chitosan nanocomposite: A promising nano-adsorbent for the removal of 2naphthol from aqueous solution and their kinetic studies, Int. J. Biol. Macromol. 159 (2020) 530-538. https://doi.org/10.1016/j.ijbiomac.2020.05.113.

[30] G. Crini, Recent developments in polysaccharide-based materials used as adsorbents in wastewater treatment, Prog. Polym. Sci. $30 \quad$ (2005) 38-70. https://doi.org/10.1016/j.progpolymsci.2004.11.002. 
[31] M. Vakili, M. Rafatullah, B. Salamatinia, A.Z. Abdullah, M.H. Ibrahim, K.B. Tan, Z. Gholami, P. Amouzgar, Application of chitosan and its derivatives as adsorbents for dye removal from water and wastewater: A review, Carbohydr. Polym. 113 (2014) 115-130. https://doi.org/10.1016/j.carbpol.2014.07.007.

[32] P. Rojsitthisak, S. Hansapaiboon, F.N. Sorasitthiyanukarn, S. Limpanart, Montmorillonite/carboxymethylcellulose-composite hydrogel beads as biodegradable adsorbent for dye removal, Maejo Int. J. Sci. Technol. 13 (2019) 170-184.

[33] M. Malakootian, A. Nasiri, H. Mahdizadeh, Metronidazole adsorption on CoFe2O4 /activated carbon@chitosan as a new magnetic biocomposite: Modelling, analysis, and optimization by response surface methodology, Desalin. Water Treat. 164 (2019) 215227. https://doi.org/10.5004/dwt.2019.24433.

[34] M. Malakootian, M. Hashemi, A. Toolabi, A. Nasiri, Investigation of nickel removal using poly(amidoamine) generation 4 dendrimer (PAMAM G4) from aqueous solutions, J. Eng. Res. 6 (2018) 13-23. https://www.scopus.com/inward/record.uri?eid=2-s2.0$85052899658 \&$ partnerID=40\&md5=901d42be3f1ed6a2a04dbe6fa0496254.

[35] D.T. Reis, S.Q. de Aguiar Filho, C.G.L. Grotto, M.F.R. Bihain, D.H. Pereira, Carboxymethylcellulose and cellulose xanthate matrices as potential adsorbent material for potentially toxic $\mathrm{Cr} 3+, \mathrm{Cu} 2+$ and $\mathrm{Cd} 2+$ metal ions: a theoretical study, Theor. Chem. Acc. 139 (2020). https://doi.org/10.1007/s00214-020-02610-2.

[36] C. Yawen, F. Yuan, X. Wang, Z. Sun, Y. Chen, Z. Liu, X. Wang, S. Yang, S. Wang, Synthesis of core-shell structured Fe3O4@ carboxymethylcellulose magnetic composite for highly efficient removal of $\mathrm{Eu}(\mathrm{III})$, Cellulose. 24 (2016). https://doi.org/10.1007/s10570-016-1094-8.

[37] H.P.S. Abdul Khalil, E.W.N. Chong, F.A.T. Owolabi, M. Asniza, Y.Y. Tye, S. Rizal, M.R. Nurul Fazita, M.K. Mohamad Haafiz, Z. Nurmiati, M.T. Paridah, Enhancement of basic properties of polysaccharide-based composites with organic and inorganic fillers: A review, J. Appl. Polym. Sci. 136 (2019). https://doi.org/10.1002/app.47251.

[38] S.F. Wang, L. Shen, Y.J. Tong, L. Chen, I.Y. Phang, P.Q. Lim, T.X. Liu, Biopolymer chitosan/montmorillonite nanocomposites: Preparation and characterization, Polym. $\begin{array}{llll}\text { Degrad. } & \text { Stab. } & 90 & \text { (2005) }\end{array}$ https://doi.org/https://doi.org/10.1016/j.polymdegradstab.2005.03.001.

[39] S. Abdelkrim, A. Mokhtar, A. Djelad, F. Bennabi, A. Souna, A. Bengueddach, M. Sassi, Chitosan/Ag-Bentonite Nanocomposites: Preparation, Characterization, Swelling and Biological Properties, J. Inorg. Organomet. Polym. Mater. 30 (2020) 831-840. https://doi.org/10.1007/s10904-019-01219-8.

[40] M. Rajiv Gandhi, N. Viswanathan, S. Meenakshi, Preparation and application of alumina/chitosan biocomposite, Int. J. Biol. Macromol. 47 (2010) 146-154. https://doi.org/https://doi.org/10.1016/j.ijbiomac.2010.05.008.

[41] X. Sun, Z. Tang, M. Pan, Z. Wang, H. Yang, H. Liu, Chitosan/kaolin composite porous microspheres with high hemostatic efficacy, Carbohydr. Polym. 177 (2017) 135-143. https://doi.org/https://doi.org/10.1016/j.carbpol.2017.08.131.

[42] A. Morsli, A. Bengueddach, F. Di Renzo, F. Quignard, Zeolite-chitosan composites: promising materials for catalysis and separation, in: A. Gédéon, P. Massiani, F.B.T.-S. in S.S. and C. Babonneau (Eds.), Zeolites Relat. Mater. Trends, Targets Challenges, 
Elsevier, 2008: pp. 1143-1146. https://doi.org/https://doi.org/10.1016/S01672991(08)80088-2.

[43] I. Khalil, K. Thomas, H. Jabraoui, P. Bazin, F. Maugé, Selective elimination of phenol from hydrocarbons by zeolites and silica-based adsorbents-Impact of the textural and $\begin{array}{llllll}\text { acidic properties, } & \text { J. Hazard. }\end{array}$ https://doi.org/10.1016/j.jhazmat.2019.121397.

[44] X. Chen, J. Cui, X. Xu, B. Sun, L. Zhang, W. Dong, C. Chen, D. Sun, Bacterial cellulose/attapulgite magnetic composites as an efficient adsorbent for heavy metal ions and dye treatment, Carbohydr. Polym. 229 (2020). https://doi.org/10.1016/j.carbpol.2019.115512.

[45] Z. Zhang, H. Li, J. Li, X. Li, Z. Wang, X. Liu, L. Zhang, A novel adsorbent of core-shell construction of chitosan-cellulose magnetic carbon foam: Synthesis, characterization and application to remove copper in wastewater, Chem. Phys. Lett. 731 (2019). https://doi.org/10.1016/j.cplett.2019.07.001.

[46] A.H. Nordin, N. Ngadi, Z. Mohamad, M. Jusoh, A. Arsad, Chemical regeneration of modified magnetic-PEI-cellulose adsorbent for removal of anionic reactive black 5 dyes, Int. J. Recent Technol. Eng. 7 (2019) 1629-1632.

[47] S. Karami, B. Zeynizadeh, Reduction of 4-nitrophenol by a disused adsorbent: EDAfunctionalized magnetic cellulose nanocomposite after the removal of $\mathrm{Cu} 2+$, Carbohydr. Polym. 211 (2019) 298-307. https://doi.org/10.1016/j.carbpol.2019.01.113.

[48] C. Ding, Y. Sun, Y. Wang, J. Li, Y. Lin, W. Sun, C. Luo, Adsorbent for resorcinol removal based on cellulose functionalized with magnetic poly(dopamine), Int. J. Biol. Macromol. 99 (2017) 578-585. https://doi.org/10.1016/j.ijbiomac.2017.03.018.

[49] X. Sun, L. Yang, Q. Li, J. Zhao, X. Li, X. Wang, H. Liu, Amino-functionalized magnetic cellulose nanocomposite as adsorbent for removal of Cr(VI): Synthesis and adsorption studies, Chem. Eng. J. 241 (2014) 175-183. https://doi.org/10.1016/j.cej.2013.12.051.

[50] M. Anbia, F. Rahimi, Adsorption of platinum(IV) from an aqueous solution with magnetic cellulose functionalized with thiol and amine as a nano-active adsorbent, J. Appl. Polym. Sci. 134 (2017). https://doi.org/10.1002/app.45361.

[51] J. Lu, R.-N. Jin, C. Liu, Y.-F. Wang, X.-K. Ouyang, Magnetic carboxylated cellulose nanocrystals as adsorbent for the removal of $\mathrm{Pb}$ (II) from aqueous solution, Int. J. Biol. Macromol. 93 (2016) 547-556. https://doi.org/10.1016/j.ijbiomac.2016.09.004.

[52] X. Luo, J. Zeng, S. Liu, L. Zhang, An effective and recyclable adsorbent for the removal of heavy metal ions from aqueous system: Magnetic chitosan/cellulose microspheres, $\begin{array}{llll}\text { Bioresour. } & \text { Technol. } & 194 & \text { (2015) }\end{array}$ https://doi.org/10.1016/j.biortech.2015.07.044.

[53] Y. Zhou, S. Fu, L. Zhang, H. Zhan, M. V Levit, Use of carboxylated cellulose nanofibrils-filled magnetic chitosan hydrogel beads as adsorbents for $\mathrm{Pb}(\mathrm{II})$, Carbohydr. Polym. 101 (2014) 75-82. https://doi.org/10.1016/j.carbpol.2013.08.055.

[54] D. Datta, Ö. Kerkez Kuyumcu, Ş.S. Bayazit, M. Abdel Salam, Adsorptive removal of malachite green and Rhodamine B dyes on Fe3O4/activated carbon composite, J. Dispers. $\quad$ Sci. $\quad$ Technol. $38 \quad$ (2017) 1556-1562. https://doi.org/10.1080/01932691.2016.1262776. 
[55] B. Tang, Y. Lin, P. Yu, Y. Luo, Study of aniline/E-caprolactam mixture adsorption from aqueous solution onto granular activated carbon: Kinetics and equilibrium, Chem. Eng. J. 187 (2012) 69-78. https://doi.org/https://doi.org/10.1016/j.cej.2012.01.088.

[56] M. Malakootian, A. Nasiri, A. Asadipour, M. Faraji, E. Kargar, A facile and green method for synthesis of $\mathrm{ZnFe} 2 \mathrm{O} 4 @ \mathrm{CMC}$ as a new magnetic nanophotocatalyst for ciprofloxacin removal from aqueous media, MethodsX. 6 (2019) 1575-1580. https://doi.org/10.1016/j.mex.2019.06.018.

[57] M. Malakootian, A. Nasiri, A. Asadipour, E. Kargar, Facile and green synthesis of $\mathrm{ZnFe} 2 \mathrm{O} 4 @ \mathrm{CMC}$ as a new magnetic nanophotocatalyst for ciprofloxacin degradation from aqueous media, Process Saf. Environ. Prot. 129 (2019) 138-151. https://doi.org/10.1016/j.psep.2019.06.022.

[58] K. Balarak, D; Mansouri, AH; Chandrika, adsorption characteristics of metronidazole from industrial wastewater onto polyaniline nanocomposite, Int. J. Life Sci. Pharma Res. 4 (2019) 49-58. 
Figure and Table Captions:

Figure 1. Schematic representation of $\mathrm{CoFe}_{2} \mathrm{O}_{4} @ \mathrm{CMC} / \mathrm{HZSM}-5$ synthesis

Figure 2. The FT-IR spectrum of CMC, HZSM-5, and $\mathrm{CoFe}_{2} \mathrm{O}_{4} @ \mathrm{CMC} / \mathrm{HZSM}-5$ magnetic nanoadsorbent

Figure 3. The FESEM (a, b) and TEM (c) images of $\mathrm{CoFe}_{2} \mathrm{O}_{4} @ \mathrm{CMC} / \mathrm{HZSM}-5$ magnetic nanoadsorbent

Figure 4. The EDS of $\mathrm{CoFe}_{2} \mathrm{O}_{4} @ \mathrm{CMC} / \mathrm{HZSM}-5$ magnetic nanoadsorbent

Figure 5. The Mapping of $\mathrm{CoFe}_{2} \mathrm{O}_{4} @ \mathrm{CMC} / \mathrm{HZSM}-5$ magnetic nanoadsorbent

Figure 6. The XRD patterns of CMC, $\mathrm{HZSM}-5, \mathrm{CoFe}_{2} \mathrm{O}_{4}$, and $\mathrm{CoFe}_{2} \mathrm{O}_{4} @ \mathrm{CMC} / \mathrm{HZSM}-5$ magnetic nanoadsorbent

Figure 7. Magnetic hysteresis curve of $\mathrm{CoFe}_{2} \mathrm{O}_{4} @ \mathrm{CMC} / \mathrm{HZSM}-5$ magnetic nanoadsorbent

Figure 8. The TGA analysis of $\mathrm{CoFe}_{2} \mathrm{O}_{4} @ \mathrm{CMC} / \mathrm{HZSM}-5$ magnetic nanoadsorbent

Figure 9. The effect of $\mathrm{pH}$ changes on the metronidazole removal rate by $\mathrm{MNZ}=50 \mathrm{mg} / \mathrm{L}$, adsorbent dose $=2 \mathrm{~g} / \mathrm{L}, \mathrm{T}=20^{\circ} \mathrm{C}$ )

Figure 10. The effect of contact time changes on the metronidazole removal rate by $\mathrm{CoFe}_{2} \mathrm{O}_{4} @ \mathrm{CMC} / \mathrm{HZSM}-5$ (pH=6, MNZ=50 mg/L, adsorbent dose=2 g/L, T=20 ${ }^{\circ} \mathrm{C}$ )

Figure 11. (a) The effect of adsorbent value changes and (b) the effect of adsorbates concentration changes on the removal efficiency by $\mathrm{CoFe}_{2} \mathrm{O}_{4} @ \mathrm{CMC} / \mathrm{HZSM}-5(\mathrm{pH}$ $=6, \mathrm{~T}=20^{\circ} \mathrm{C}$ )

Figure 12. The kinetic model curves of the metronidazole adsorption process by $\mathrm{CoFe}_{2} \mathrm{O}_{4} @ \mathrm{CMC} / \mathrm{HZSM}-5(\mathrm{pH}=6, \mathrm{MNZ}=50 \mathrm{mg} / \mathrm{L}$, adsorbent dose= $2 \mathrm{~g} / \mathrm{L}, \mathrm{T}=20$ $\left.{ }^{\circ} \mathrm{C}\right)$

Figure 13. Metronidazole adsorption process equilibrium models by $\mathrm{CoFe}_{2} \mathrm{O}_{4} @ \mathrm{CMC} / \mathrm{HZSM}-$ $5(\mathrm{pH}=6, \mathrm{MNZ}=50 \mathrm{mg} / \mathrm{L}$, adsorbent dose $=2 \mathrm{~g} / \mathrm{L}, \mathrm{t}=60 \mathrm{~min})$

Figure 14. Metronidazole adsorption process Vant Hoff curve

Figure 15. Comparison of metronidazole adsorption by $\mathrm{CoFe}_{2} \mathrm{O}_{4}, \mathrm{CMC}, \mathrm{HZSM}-5$, and $\mathrm{CoFe}_{2} \mathrm{O}_{4} @ \mathrm{CMC} / \mathrm{HZSM}-5$ adsorbents $(\mathrm{pH}=6, \mathrm{MNZ}=50 \mathrm{mg} / \mathrm{L}$, adsorbent dose $=2$ $\mathrm{g} / \mathrm{L})$

Figure 16. Proposed mechanism of metronidazole removal by $\mathrm{CoFe}_{2} \mathrm{O}_{4} @ \mathrm{CMC} / \mathrm{HZSM}-5$

Figure 17. Recycling of $\mathrm{CoFe}_{2} \mathrm{O}_{4} @ \mathrm{CMC} / \mathrm{HZSM}-5(\mathrm{pH}=6, \mathrm{MNZ}=50 \mathrm{mg} / \mathrm{L}$, adsorbent dose=2 g/L) (a), FESEM (b) and XRD pattern (c) of $\mathrm{CoFe}_{2} \mathrm{O}_{4} @ \mathrm{CMC} / \mathrm{HZSM}-5$ magnetic nanoadsorbent after the sixth run of recycling

Table 1. Metronidazole removal kinetic parameters by $\mathrm{CoFe}_{2} \mathrm{O}_{4} @ \mathrm{CMC} / \mathrm{HZSM}-5$

Table 2. Metronidazole adsorption process equilibrium isotherms of by $\mathrm{CoFe}_{2} \mathrm{O}_{4} @ \mathrm{CMC} / \mathrm{HZSM}-5$

Table 3. The thermodynamic parameters of metronidazole adsorption process by $\mathrm{CoFe}_{2} \mathrm{O}_{4} @ \mathrm{CMC} / \mathrm{HZSM}-5$ 
Figures
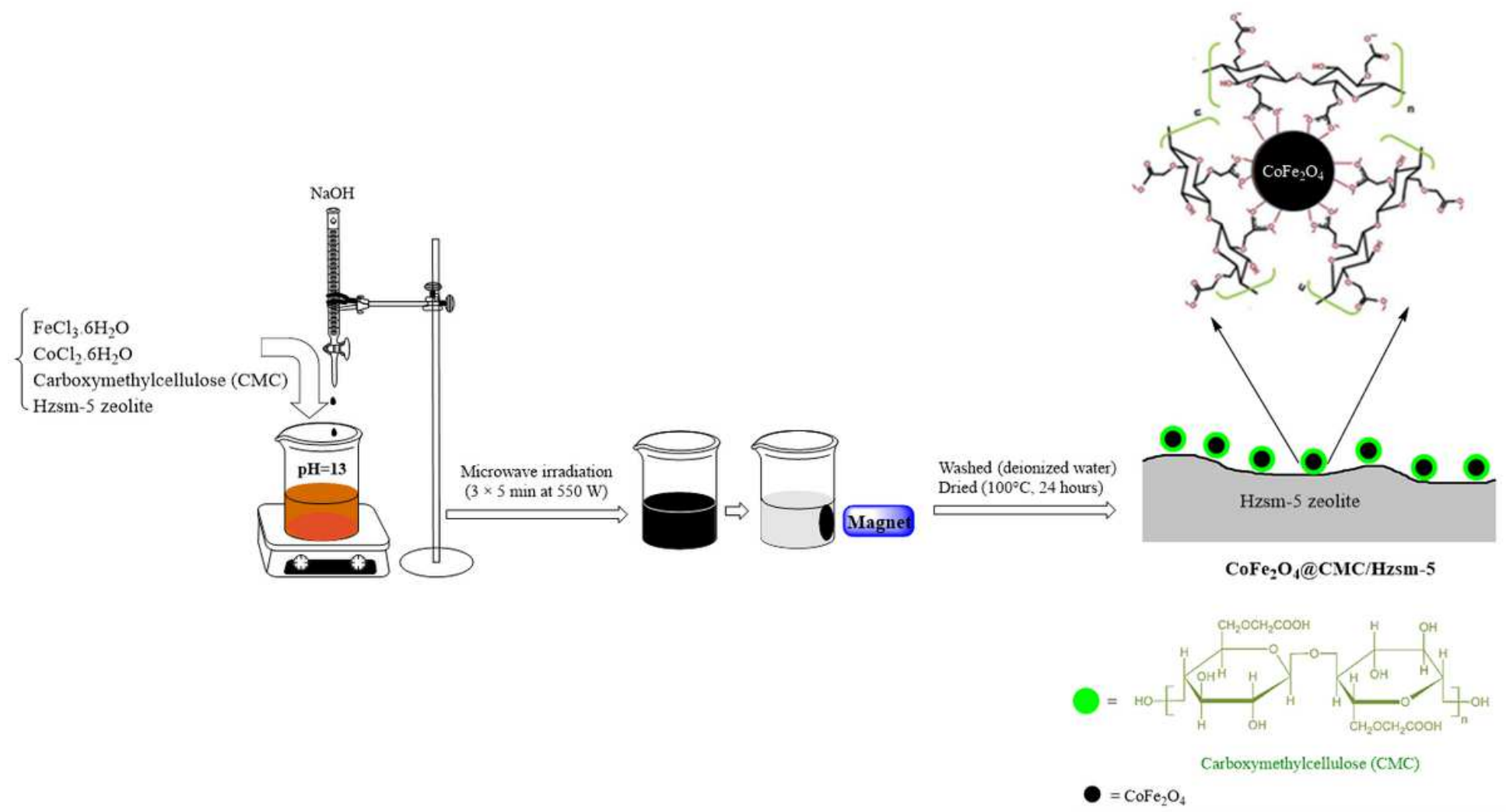

Figure 1

Schematic representation of CoFe204@CMC/HZSM-5 synthesis 


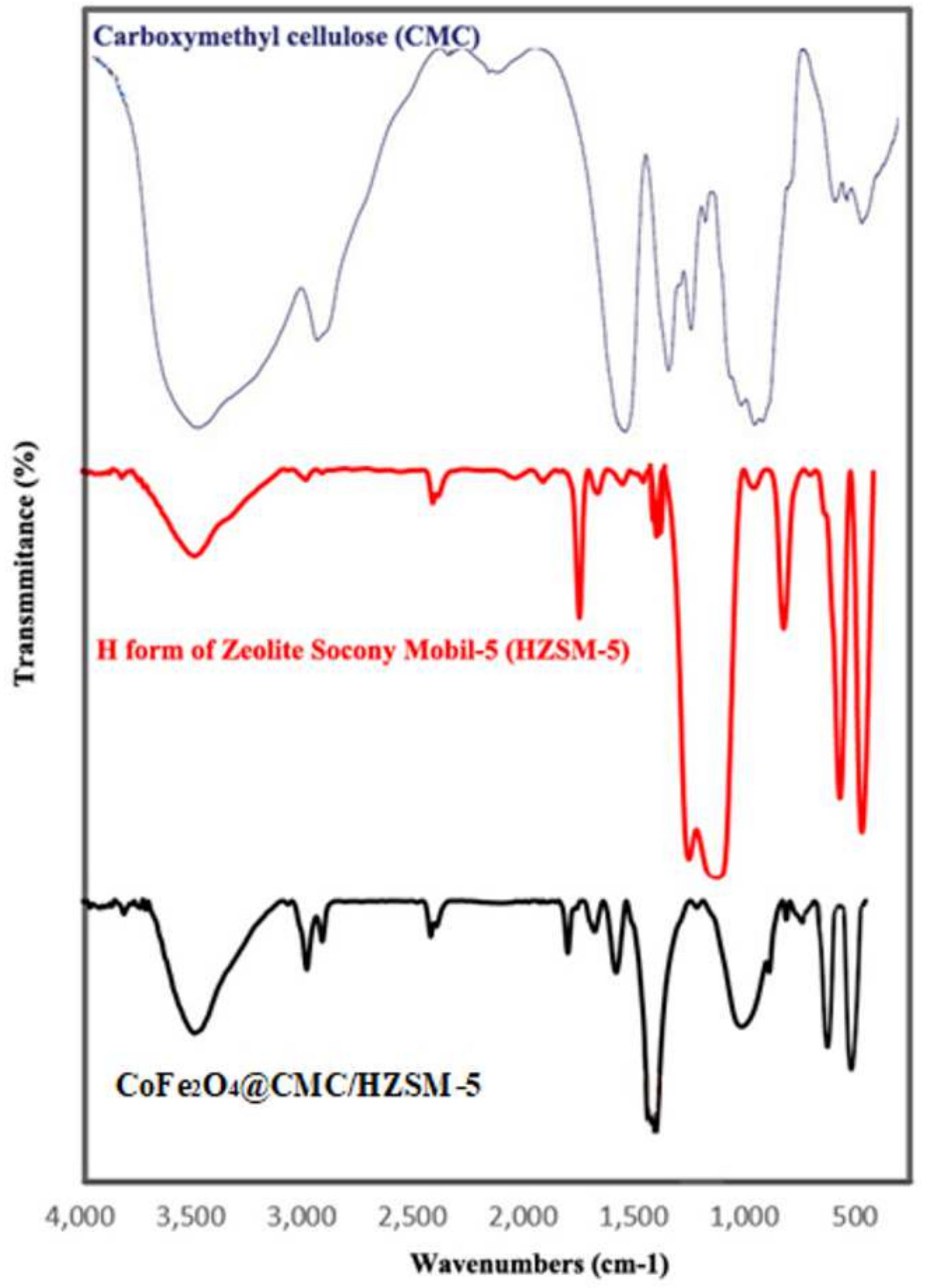

Figure 2

The FT-IR spectrum of CMC, HZSM-5, and CoFe2O4@CMC/HZSM-5 magnetic nanoadsorbent 

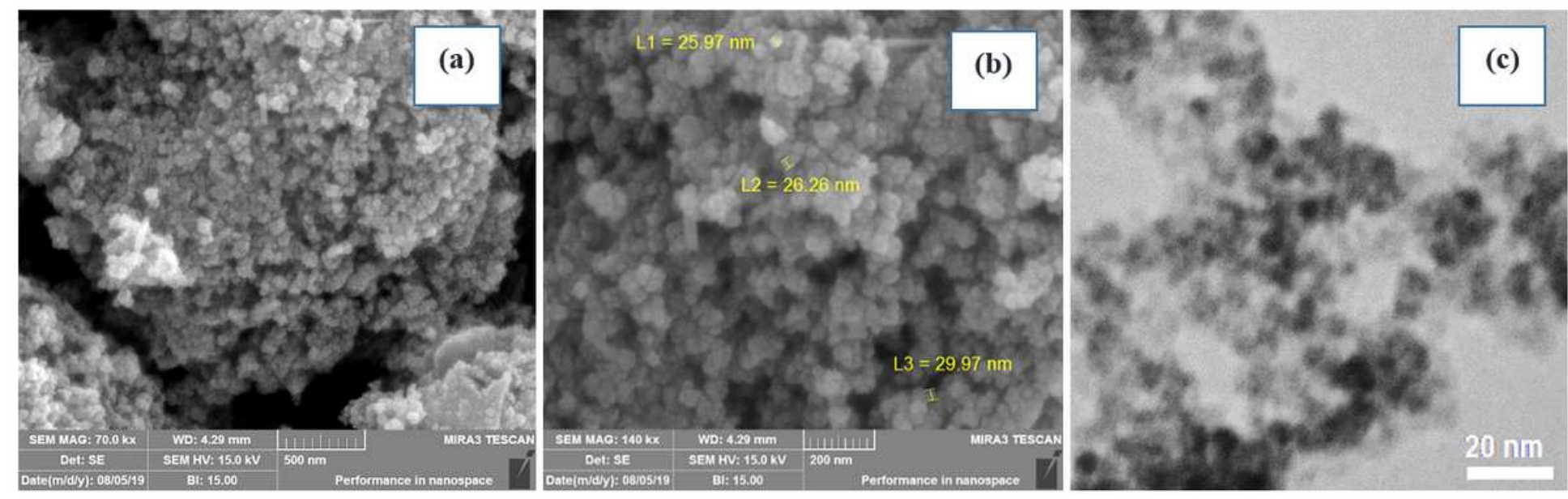

\section{Figure 3}

The FESEM (a, b) and TEM (c) images of CoFe2O4@CMC/HZSM-5 magnetic nanoadsorbent

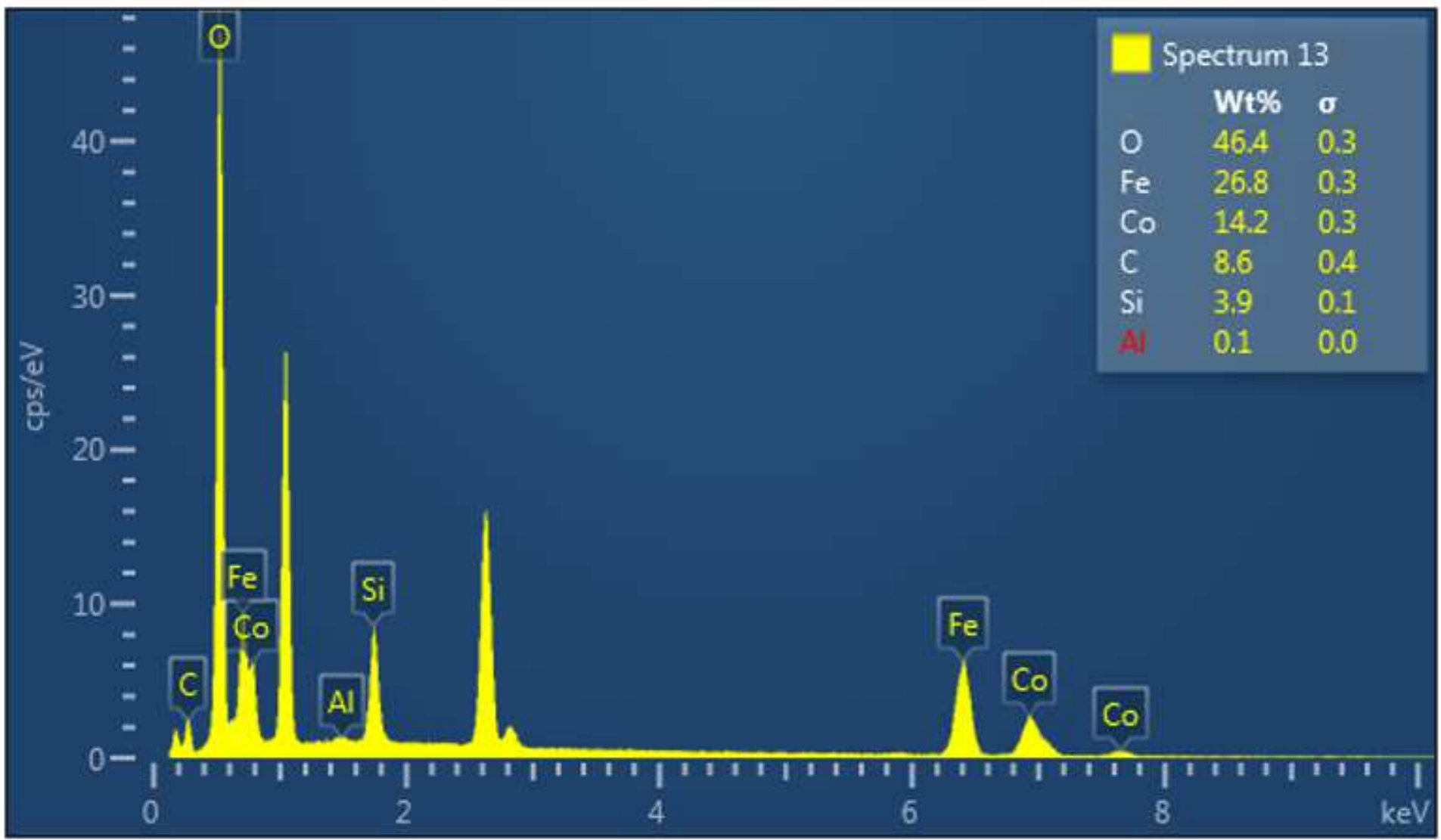

\section{Figure 4}

The EDS of CoFe204@CMC/HZSM-5 magnetic nanoadsorbent 

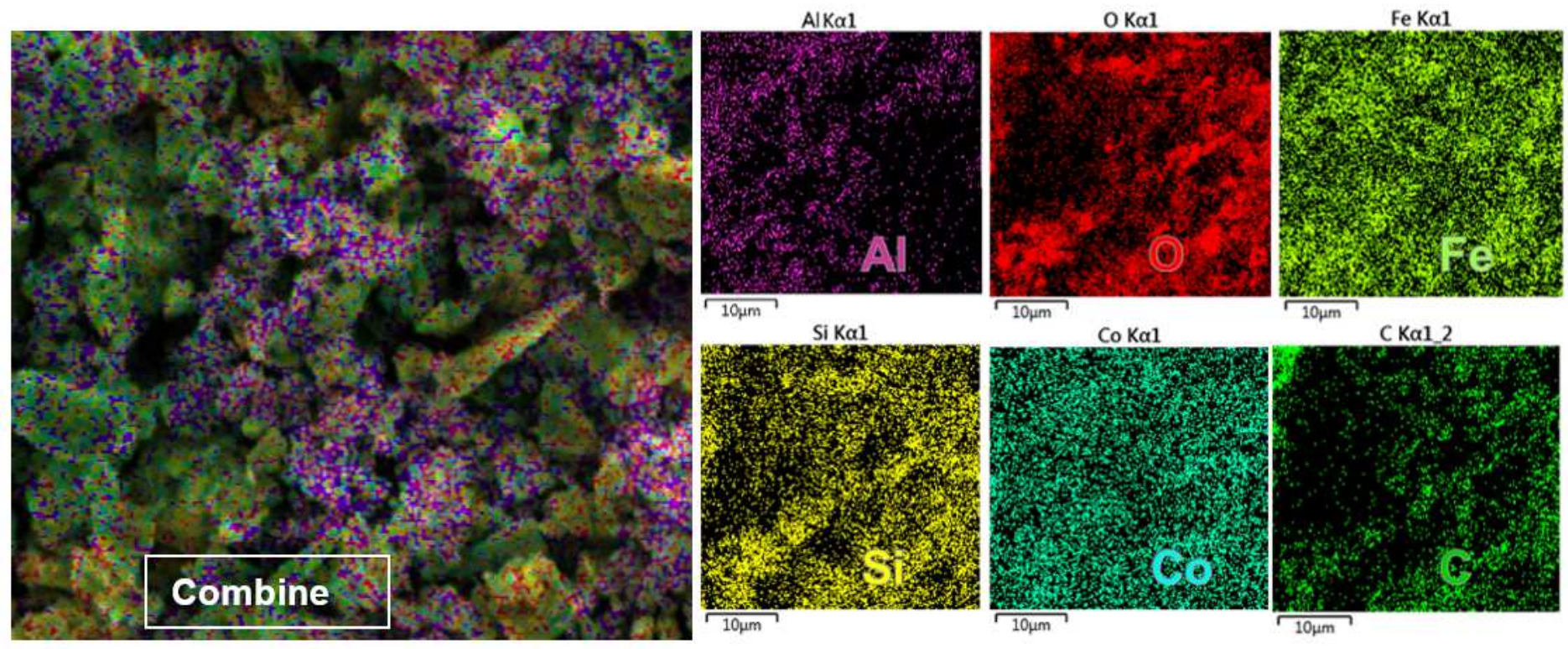

$\mathrm{CKa12}$

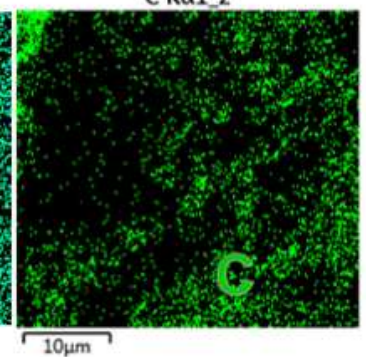

Figure 5

The Mapping of CoFe2O4@CMC/HZSM-5 magnetic nanoadsorbent 


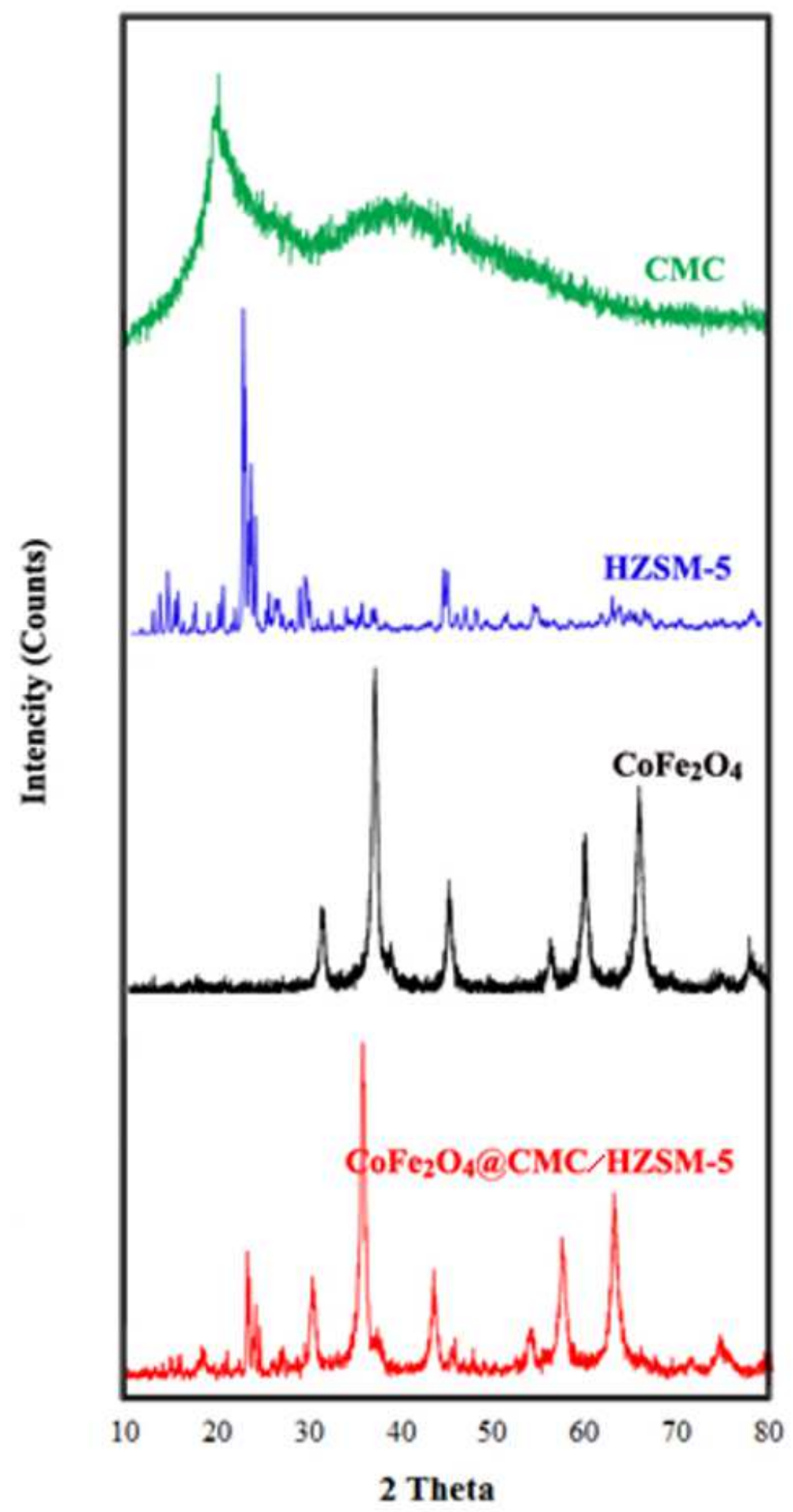

Figure 6

The XRD patterns of CMC, HZSM-5, CoFe2O4, and CoFe2O4@CMC/HZSM-5 magnetic nanoadsorbent 


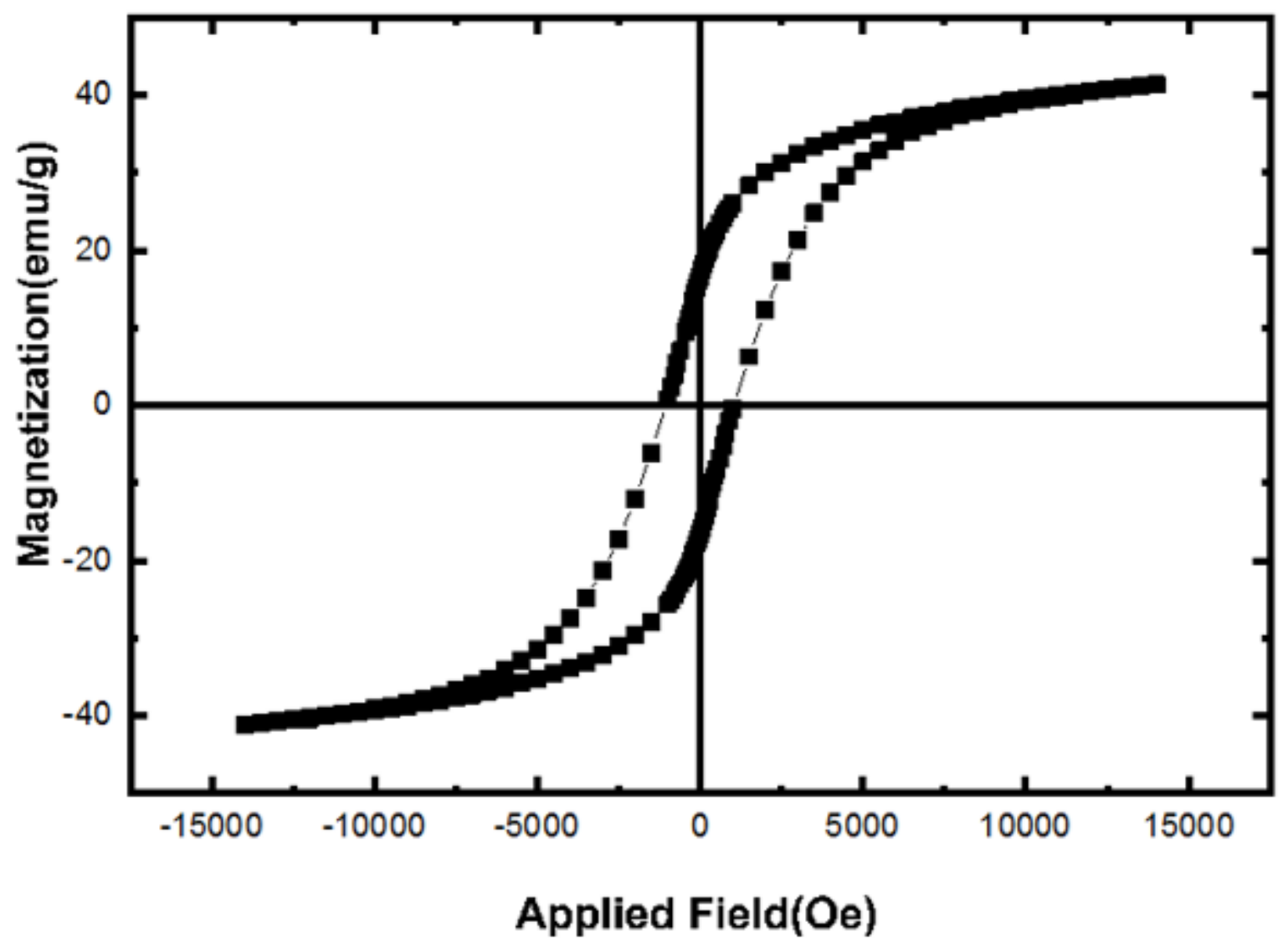

Figure 7

Magnetic hysteresis curve of CoFe2O4@CMC/HZSM-5 magnetic nanoadsorbent 


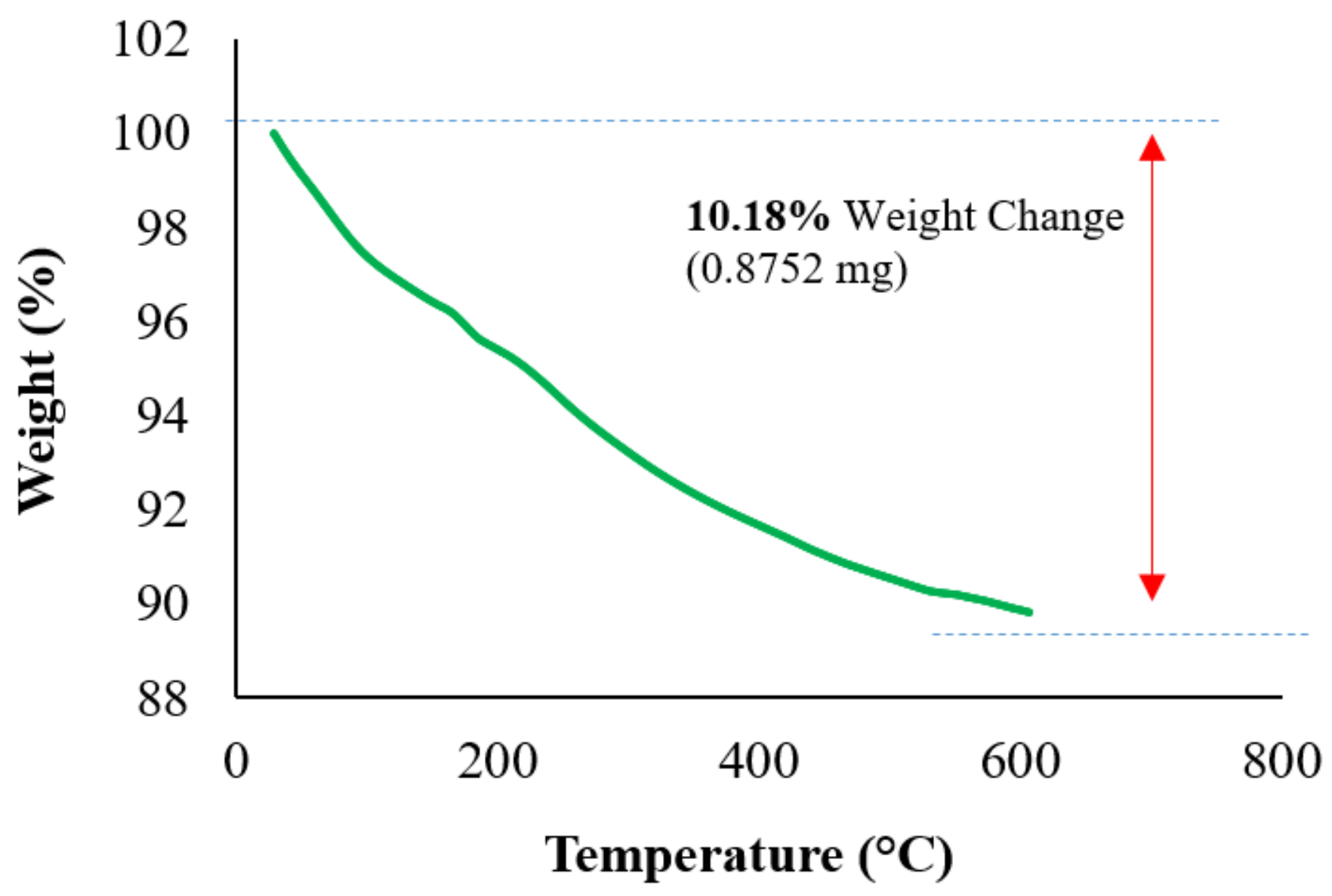

Figure 8

The TGA analysis of CoFe2O4@CMC/HZSM-5 magnetic nanoadsorbent 


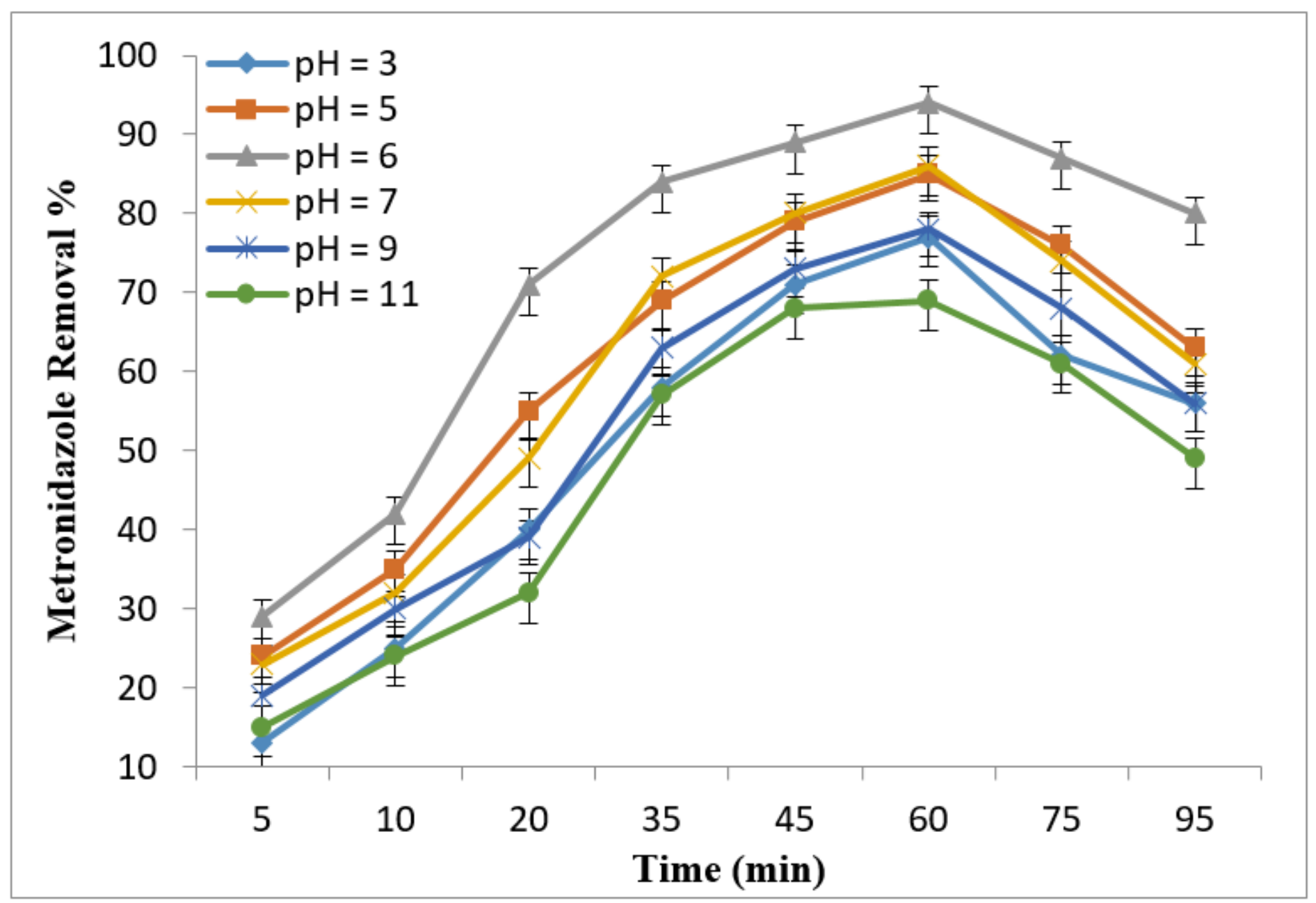

Figure 9

The effect of $\mathrm{pH}$ changes on the metronidazole removal rate by MNZ $=50 \mathrm{mg} / \mathrm{L}$, adsorbent dose $=2 \mathrm{~g} / \mathrm{L}$, $\mathrm{T}=20 \mathrm{oC})$ 


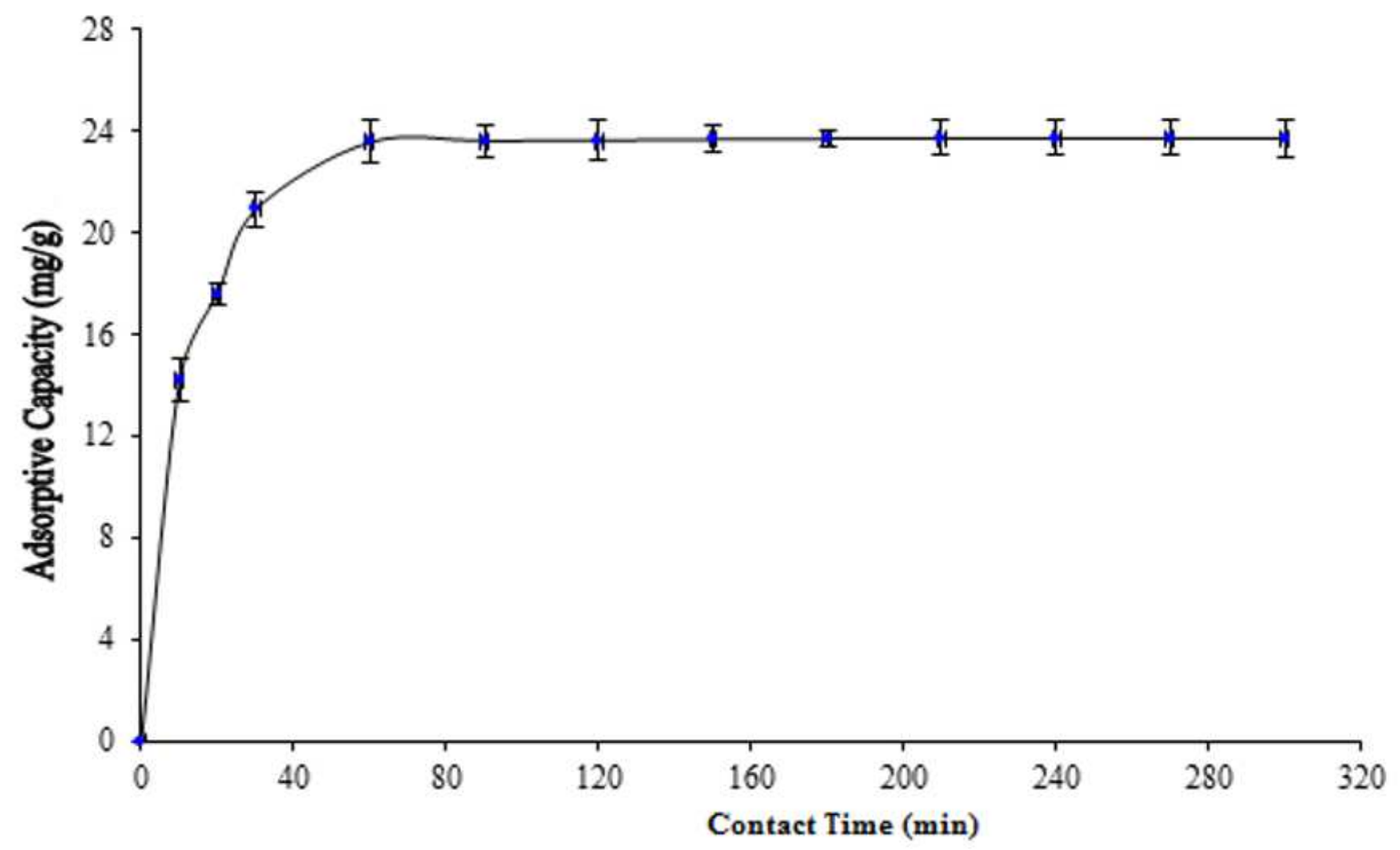

Figure 10

The effect of contact time changes on the metronidazole removal rate by CoFe204@CMC/HZSM-5 $(\mathrm{pH}=6, \mathrm{MNZ}=50 \mathrm{mg} / \mathrm{L}$, adsorbent dose $=2 \mathrm{~g} / \mathrm{L}, \mathrm{T}=20 \mathrm{oC}$ )

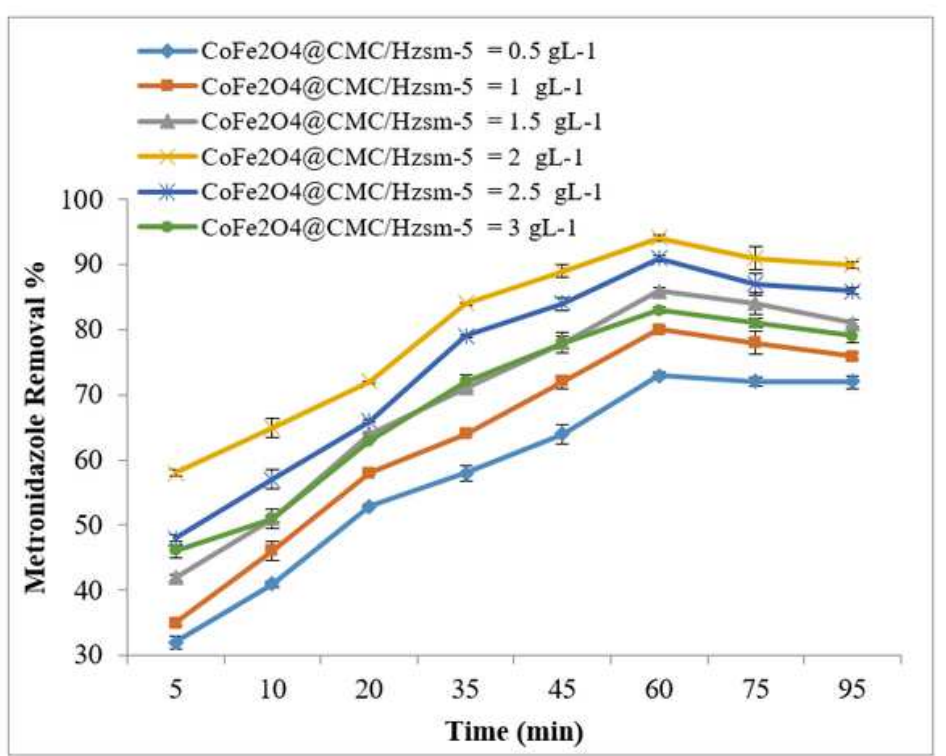

A

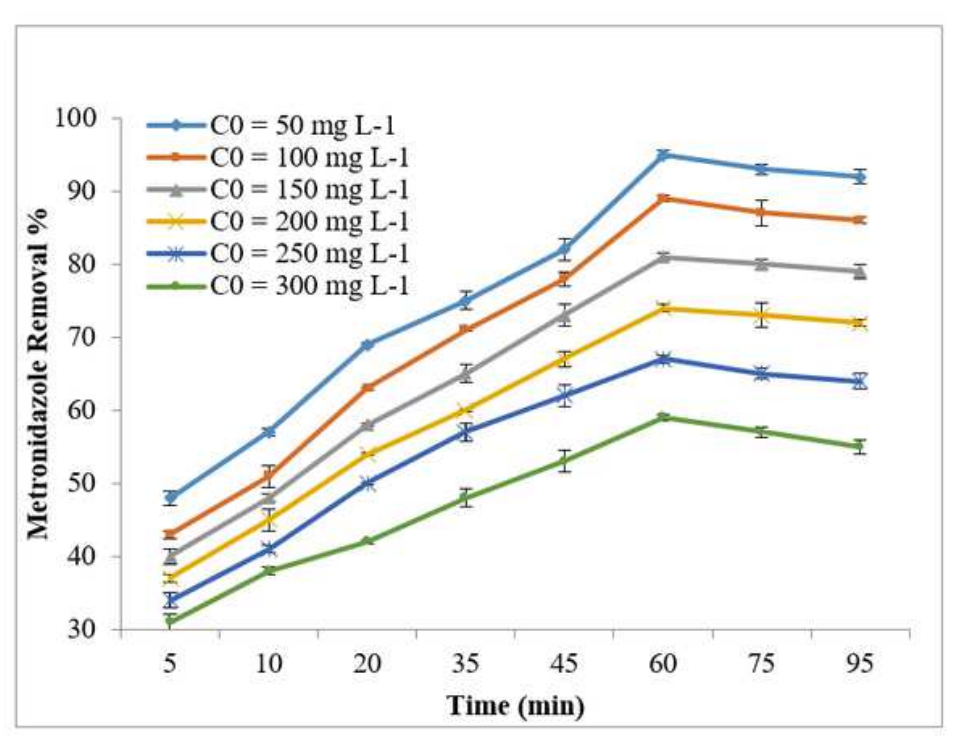

B

Figure 11 
(a) The effect of adsorbent value changes and (b) the effect of adsorbates concentration changes on the removal efficiency by CoFe2O4@CMC/HZSM-5 ( $\mathrm{pH}=6, \mathrm{~T}=20$ oC)

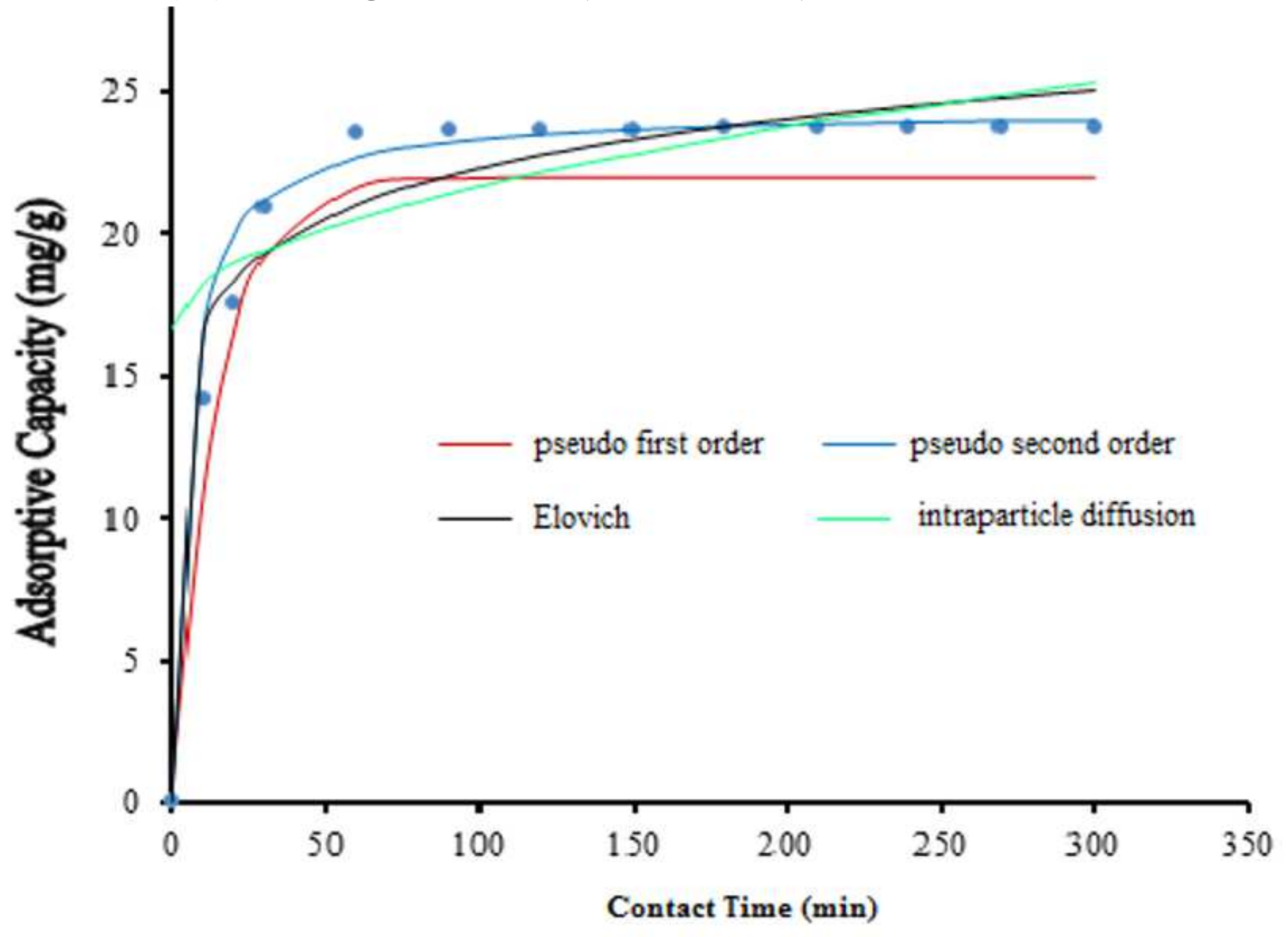

Figure 12

The kinetic model curves of the metronidazole adsorption process by CoFe2O4@CMC/HZSM-5 (pH = 6, $\mathrm{MNZ}=50 \mathrm{mg} / \mathrm{L}$, adsorbent dose $=2 \mathrm{~g} / \mathrm{L}, \mathrm{T}=20 \mathrm{oC}$ ) 


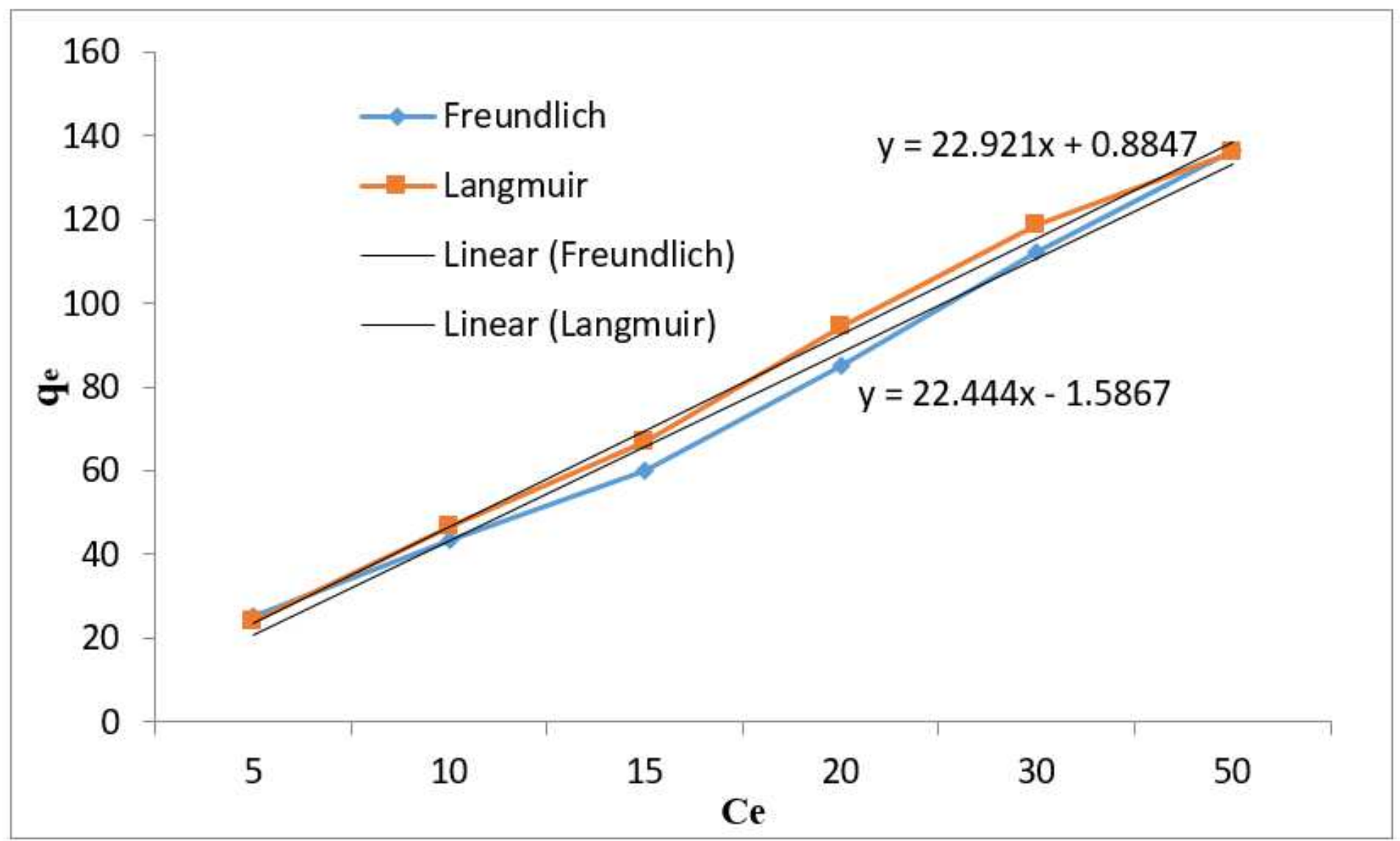

Figure 13

Metronidazole adsorption process equilibrium models by CoFe2O4@CMC/HZSM-5 (pH = 6, MNZ = 50 $\mathrm{mg} / \mathrm{L}$, adsorbent dose $=2 \mathrm{~g} / \mathrm{L}, \mathrm{t}=60 \mathrm{~min}$ ) 


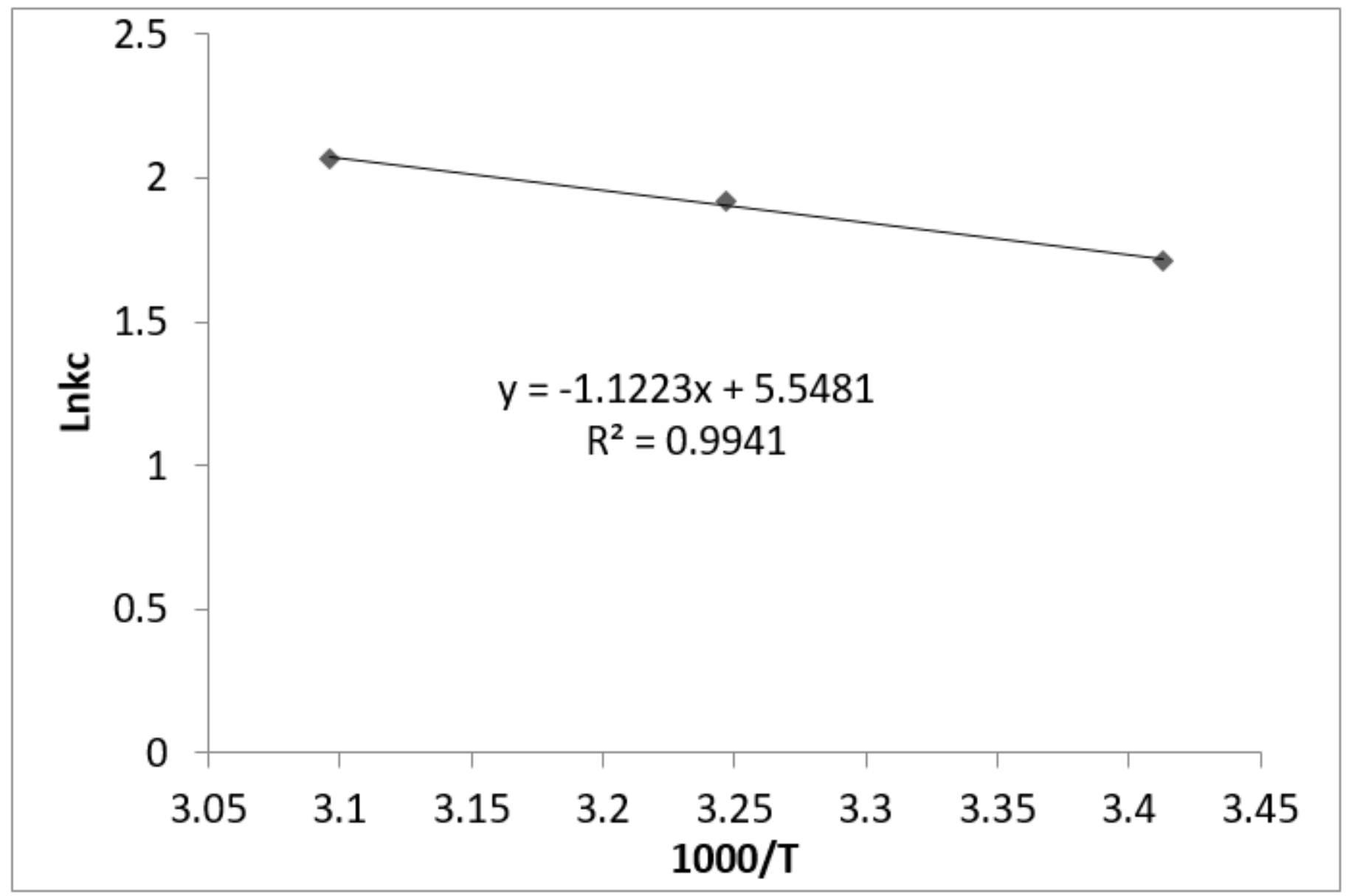

Figure 14

Metronidazole adsorption process Vant Hoff curve 


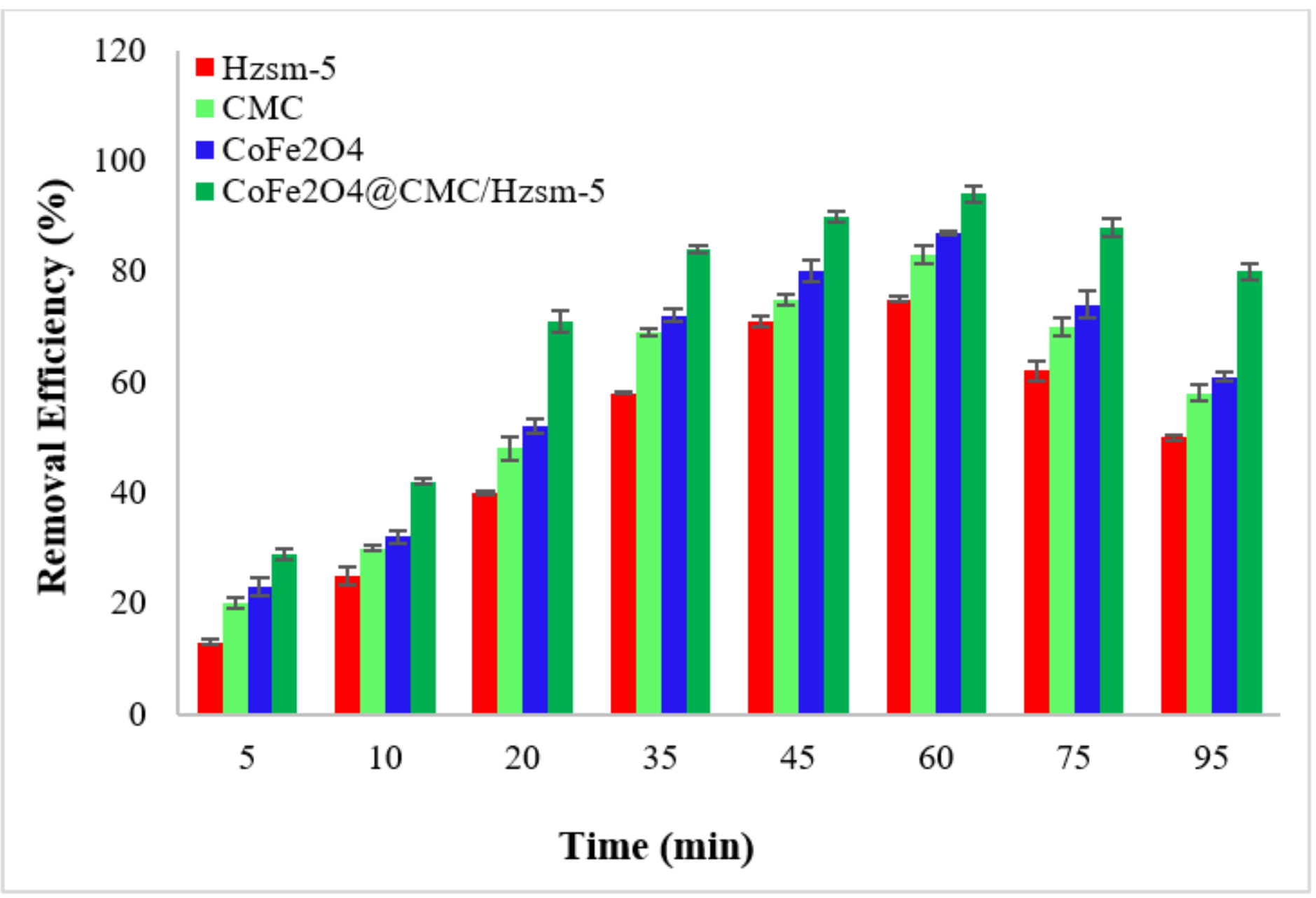

Figure 15

Comparison of metronidazole adsorption by CoFe2O4, CMC, HZSM-5, and CoFe2O4@CMC/HZSM-5 adsorbents $(\mathrm{pH}=6, \mathrm{MNZ}=50 \mathrm{mg} / \mathrm{L}$, adsorbent dose $=2 \mathrm{~g} / \mathrm{L})$ 


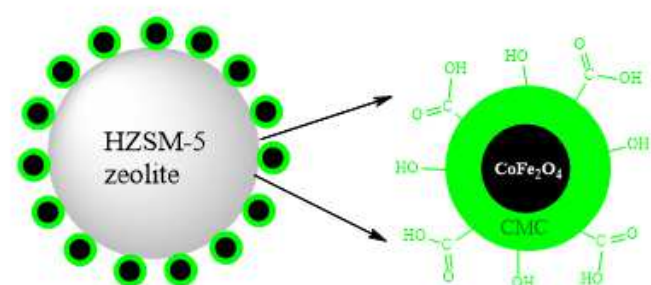

$\mathrm{CoFe}_{2} \mathrm{O}_{4} @$ CMC@HZSM-5
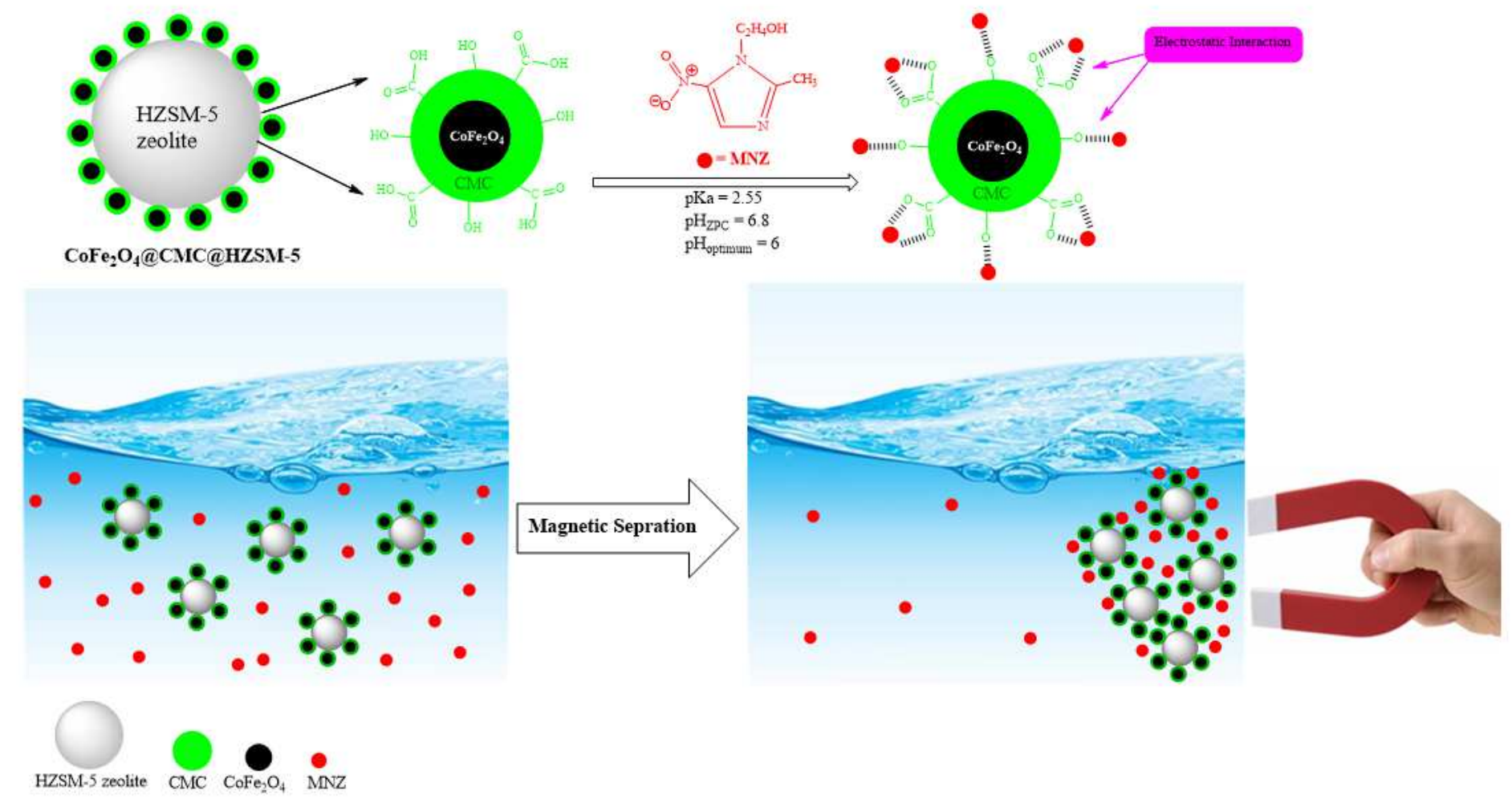

Figure 16

Proposed mechanism of metronidazole removal by CoFe204@CMC/HZSM-5 

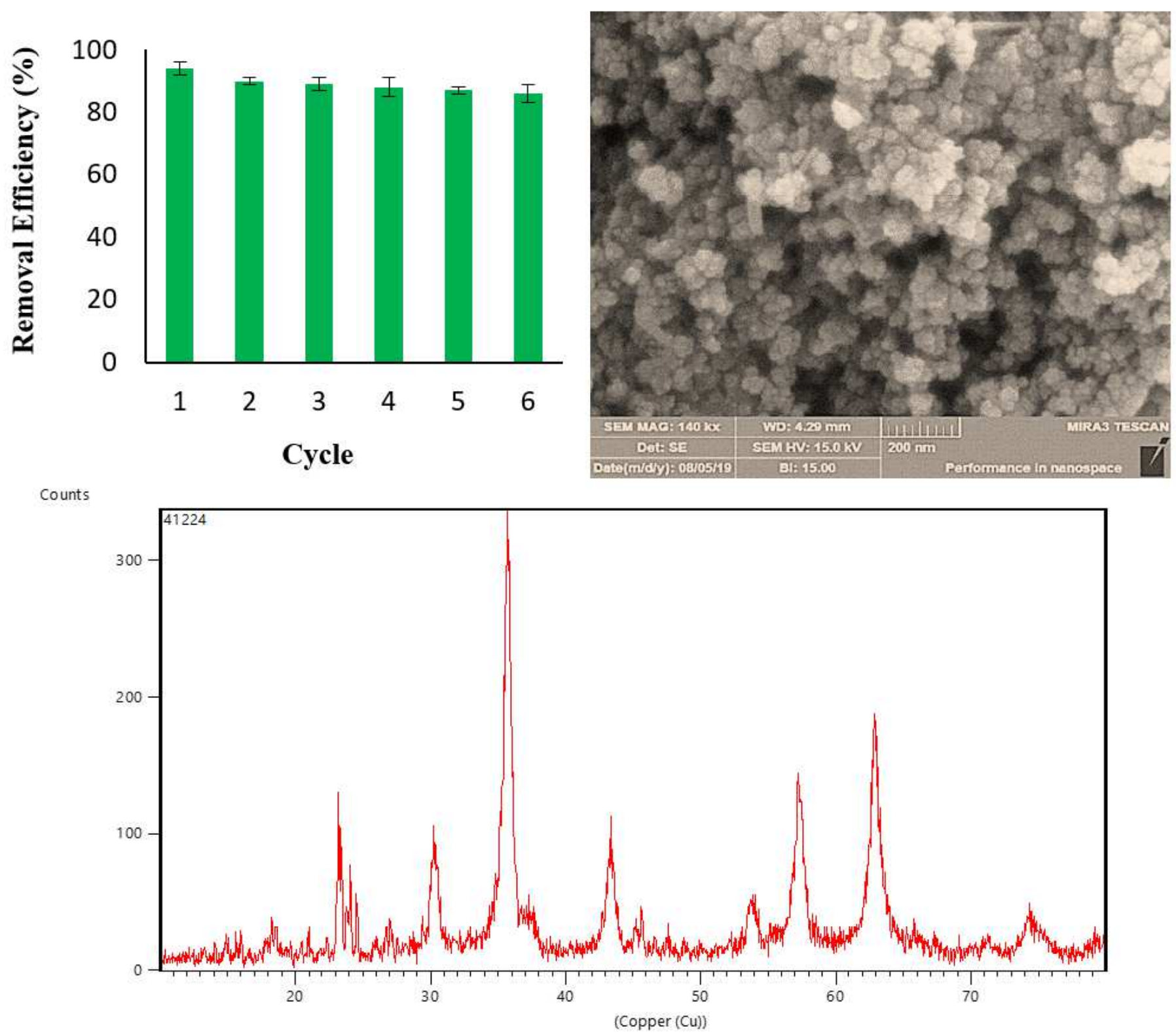

Figure 17

Recycling of CoFe2O4@CMC/HZSM-5 (pH = 6, MNZ= 50 mg/L, adsorbent dose=2 g/L) (a), FESEM (b) and XRD pattern (c) of CoFe204@CMC/HZSM-5 magnetic nano adsorbent after the sixth run of recycling 